\title{
Single-step genome-wide association for longitudinal traits of Canadian Ayrshire, Holstein, and Jersey dairy cattle
}

\author{
H. R. Oliveira, ${ }^{1,2 *}$ D. A. L. Lourenco,${ }^{3}$ Y. Masuda, ${ }^{3}$ I. Misztal, ${ }^{3}$ S. Tsuruta, ${ }^{3}$ J. Jamrozik, ${ }^{1,4}$ L. F. Brito, ${ }^{1,5}$ \\ F. F. Silva, ${ }^{2}$ J. P. Cant, ${ }^{1}$ and F. S. Schenkel ${ }^{1}$ \\ ${ }^{1}$ Department of Animal Biosciences, University of Guelph, Guelph, ON, N1G 2W1, Canada \\ ${ }^{2}$ Department of Animal Sciences, Universidade Federal de Viçosa, Viçosa, Minas Gerais, 36570-000, Brazil \\ ${ }^{3}$ Department of Animal and Dairy Science, University of Georgia, Athens 30602 \\ ${ }^{4}$ Canadian Dairy Network, Guelph, ON, N1K 1E5, Canada \\ ${ }^{5}$ Department of Animal Sciences, Purdue University, West Lafayette, IN 47907
}

\section{ABSTRACT}

Estimating single nucleotide polymorphism (SNP) effects over time is essential to identify and validate candidate genes (or quantitative trait loci) associated with time-dependent variation of economically important traits and to better understand the underlying mechanisms of lactation biology. Therefore, in this study, we aimed to estimate time-dependent effects of SNP and identifying candidate genes associated with milk (MY), fat (FY), and protein (PY) yields, and somatic cell score (SCS) in the first 3 lactations of Canadian Ayrshire, Holstein, and Jersey breeds, as well as suggest their potential pattern of phenotypic effect over time. Random regression coefficients for the additive direct genetic effect were estimated for each animal using single-step genomic BLUP, based on 2 random regression models: one considering MY, FY, and PY in the first 3 lactations and the other considering SCS in the first 3 lactations. Thereafter, SNP solutions were obtained for random regression coefficients, which were used to estimate the SNP effects over time (from 5 to $305 \mathrm{~d}$ in lactation). The top $1 \%$ of SNP that showed a high magnitude of SNP effect in at least $1 \mathrm{~d}$ in lactation were selected as relevant SNP for further analyses of candidate genes, and clustered according to the trajectory of their SNP effects over time. The majority of SNP selected for MY, FY, and PY increased the magnitude of their effects over time, for all breeds. In contrast, for SCS, most selected SNP decreased the magnitude of their effects over time, especially for the Holstein and Jersey breeds. In general, we identified a different set of candidate genes for each breed, and similar genes were found across different lactations

Received April 17, 2019.

Accepted July 8, 2019.

*Corresponding author: holivier@uoguelph.ca for the same trait in the same breed. For some of the candidate genes, the suggested pattern of phenotypic effect changed among lactations. Among the lactations, candidate genes (and their suggested phenotypic effect over time) identified for the second and third lactations were more similar to each other than for the first lactation. Well-known candidate genes with major effects on milk production traits presented different suggested patterns of phenotypic effect across breeds, traits, and lactations in which they were identified. The candidate genes identified in this study can be used as target genes in studies of gene expression.

Key words: milk, random regression, SNP effect, testday

\section{INTRODUCTION}

Traits measured repeatedly during an individual's lifetime or physiological cycle are termed "longitudinal traits." Most economically important longitudinal traits in dairy cattle are lactation-related variables, such as milk, fat, and protein yields and SCS (Miglior et al., 2017; Oliveira et al., 2019c). The variability observed among repeated records for those longitudinal traits is due to changes in the physiological state of the animal over the lactation period. Such changes in the trait variation over the lactation period are likely due to differential gene expression or changes in the effects of QTL over time, as suggested by the changes in additive genetic variance and heritability over lactation (e.g., Miglior et al., 2009; Oliveira et al., 2017; Sasaki et al., 2017). In this context, a previous study showed evidence of differential sets of candidate genes underlying the phenotypic variation of longitudinal traits in different lactation stages of the Canadian Ayrshire, Holstein, and Jersey breeds (Oliveira et al., 2019b). Furthermore, gene expression studies have indicated that the amount of RNA synthesized often varies across lactations (Bionaz and Loor, 2008), and that specific genes or QTL 
can be differently expressed depending on the lactation stage (Strucken et al., 2011). Nonetheless, various studies on longitudinal traits have combined repeated records for each animal into a single estimate (e.g., average over all time points or accumulated yield), which are then used as response variables for genomic prediction of breeding values (e.g., Ding et al., 2013; Li et al., 2014; Jenko et al., 2017) and genome-wide association studies (GWAS; e.g., Buitenhuis et al., 2014; Raven et al., 2014; Nayeri et al., 2016).

Using a single estimate derived from repeated records when performing GWAS may compromise the understanding of the genetic architecture and underlying biological mechanisms of longitudinal traits. This approach does not enable the unraveling of genomic regions and candidate genes with differential effects along the lactation curve. For instance, a certain QTL might have a highly significant effect in a specific lactation stage (e.g., lactation peak), but when averaging its effect across the whole lactation, it might be substantially reduced, which would consequently hamper the identification of this QTL, if combining repeated records. Therefore, using statistical models that consider all the variability from repeated records can increase the statistical power to detect time-dependent QTL and, consequently, candidate genes affecting traits at specific stages of the lactation. In this context, Das et al. (2011) showed that is possible to use random regression models (RRM) to exploit specific covariance functions to describe changes in SNP effects over time. By analyzing SNP associations over time, QTL with greater effects at specific times are more likely to be identified, which may help to better explain the observed phenotypic variation in longitudinal traits over time (Strucken et al., 2015). Currently, this approach is the most sophisticated and flexible tool to perform GWAS for longitudinal traits. However, despite the SNP availability and several GWAS reports for milk-related traits in dairy cattle, the use of RRM to estimate SNP effects over time remains underexplored, especially when considering different dairy cattle breeds.

Estimating SNP effects over time for various breeds is essential to identify and validate candidate genes (or QTL) associated with time-dependent effects of economically important traits across breeds, and to better understand the underlying mechanisms of lactation biology. However, this task can be difficult because the effects of QTL and the allele frequencies can differ across breeds, especially if a small number of animals is genotyped. In populations with a smaller number of genotyped animals (e.g., Canadian Ayrshire and Jersey) the use of the single-step genomic BLUP method (ssGBLUP; Misztal et al., 2009; Aguilar et al., 2010;
Christensen and Lund, 2010) can yield more accurate genomic EBV (GEBV) for estimating the SNP effects over time. Therefore, this study aimed to (1) estimate time-dependent effects of SNP associated with milk (MY), fat (FY), and protein (PY) yields, and SCS in the first 3 lactations of Canadian Ayrshire, Holstein, and Jersey breeds, using multiple-trait RRM and ssGBLUP; and (2) identify candidate genes associated with the analyzed traits, across lactations and breeds, and suggest their potential pattern of phenotypic effect.

\section{MATERIALS AND METHODS}

No animal care committee approval was necessary for the purposes of this study, as all information required was obtained from existing databases.

\section{Phenotypic, Genotypic, and Pedigree Data}

The Canadian Dairy Network (CDN; Guelph, ON, Canada) provided the December 2012 pedigree, genotypes, and the MY, FY, PY, and SCS test-day records (phenotypes) from the first 3 lactations of Ayrshire, Holstein, and Jersey breeds. Phenotypic quality control was performed to remove outlier test-day records for each trait (mean $\pm 3 \mathrm{SD}$, within contemporary group, which were defined by the combination of herd and test-day), and contemporary groups that were formed from fewer than 3 animals. Details on the criteria and number of test-day records removed in each step can be found in Oliveira et al. (2019a). The average MY, FY, PY, and SCS over DIM estimated for the Ayrshire, Holstein, and Jersey breeds are shown in Supplemental Figure S1 (https://doi.org/10.3168/jds.2019-16821).

Initially, the number of animals genotyped with lowdensity $(<20 \mathrm{~K})$ SNP panels was 300, 2,270, and 202; with medium-density $(>20 \mathrm{~K}$ and $<60 \mathrm{~K})$ SNP panels was $944,17,105$, and 1,157; and with high-density (>60K) SNP panels was 749, 2,459, and 158 for Ayrshire, Holstein, and Jersey, respectively. Analyses in this study were performed using the 50K SNP panel. Therefore, only SNP present on the 50K panel were kept for the animals genotyped using high-density panels. In addition, animals genotyped with low- and medium-density panels were imputed by CDN to $50 \mathrm{~K}$ using the FImpute software (Sargolzaei et al., 2011) for each breed separately. Details about the genotype imputation process performed by CDN, as well as the average and minimum accuracy of imputation for the Canadian breeds, are presented in Larmer et al. (2014). After the imputation process, only genotyped animals born before December 2012 were kept in the analyses and used to perform genotypic quality control 
Table 1. Number of animals included in the pedigree file, herd-test-day (HTD), number of animals with phenotypes in each lactation, genotyped animals, and SNP used in the analyses for Ayrshire, Holstein, and Jersey breeds

\begin{tabular}{lccr}
\hline Trait $^{1}$ & Ayrshire & Holstein & Jersey \\
\hline MY, FY, and PY & 204,429 & $5,085,542$ & 157,718 \\
Pedigree & 104,985 & $2,258,332$ & 70,629 \\
HTD & & & \\
Phenotypes $^{2}$ & $129,912(7.57)$ & $3,791,813(7.32)$ & $89,693(6.77)$ \\
Lactation 1 & $130,094(5.13)$ & $3,789,780(5.03)$ & $89,685(4.84)$ \\
Lactation 2 & $130,112(3.79)$ & $3,795,917(3.40)$ & $89,623(3.48)$ \\
Lactation 3 $^{3}$ & $1,827(634)$ & $20,663(8,517)$ & $1,427(849)$ \\
Genotypes $^{3}$ & 38,096 & 40,658 & 34,500 \\
SNP $^{4}$ & & & \\
SCS & 195,099 & $4,983,668$ & 154,123 \\
Pedigree & 91,101 & $2,091,168$ & 64,199 \\
HTD & & & \\
Phenotypes & $121,974(6.88)$ & $3,682,503(6.84)$ & $86,102(6.29)$ \\
Lactation 1 & $122,091(4.76)$ & $3,679,049(4.74)$ & $86,187(4.50)$ \\
Lactation 2 & $122,214(3.57)$ & $3,686,040(3.23)$ & $86,257(3.27)$ \\
Lactation 3 & $1,827(634)$ & $20,663(8,517)$ & $1,427(849)$ \\
Genotypes & 38,096 & 40,658 & 34,500 \\
SNP & & & \\
\hline
\end{tabular}

${ }^{1}$ Milk (MY), fat (FY), and protein (PY) yields in the first, second, and third lactations were analyzed separately from SCS in the first, second, and third lactations.

${ }^{2}$ Number of animals with phenotypes (average number of phenotypes per animal within parentheses).

${ }^{3}$ Total number of genotyped animals (bulls within parentheses).

${ }^{4} \mathrm{SNP}$ were spread along the 29 bovine autosomes.

(within breed). Then, SNP with Mendelian conflicts, call rate $<0.95$, minor allele frequency $(\mathbf{M A F})<0.01$, and with a difference between observed and expected heterozygosity frequency $>0.15$ (Wiggans et al., 2009) were removed using the preGSf90 software (Aguilar et al., 2014). The total number of animals included in the pedigree file, herd-test-days, phenotyped animals per lactation, genotyped animals, and SNP that remained in the analyses for each breed after quality control are shown in Table 1.

\section{Statistical Analyses}

Prediction of Breeding Values. Breeding values for random regression coefficients of each animal were estimated using ssGBLUP and RRM for each breed separately. The same RRM currently used in the official genetic evaluations performed by CDN were used in this study: one considering MY, FY, and PY in the first 3 lactations (i.e., 9-trait model); and another considering SCS in the first 3 lactations (i.e., 3-trait model). Since 2016, SCS has usually been analyzed separately from the production traits to improve the stability of SCS proofs published by CDN (CDN, 2016). Both RRM included herd-test-day as fixed effect, a fixed regression for age-parity-season of calving, and random regressions for herd-year of calving, and animal additive genetic and permanent environmental effects, as routinely implemented by CDN in Canada (Interbull, 2018). All regressions were modeled using the fourth order Legendre orthogonal polynomials (Kirkpatrick et al., 1990) on DIM (which ranged from 5 to $305 \mathrm{~d}$ ).

In ssGBLUP analyses, the pedigree-based relationship matrix (A) traditionally used in the mixed model equations is replaced by the $\mathbf{H}$ matrix, which combines the pedigree and genomic information. In summary, the H matrix can be described as (Aguilar et al., 2010; Christensen and Lund, 2010):

$$
\mathbf{H}^{-1}=\mathbf{A}^{-1}+\left[\begin{array}{cc}
0 & 0 \\
0 & \tau\left(0.95 \mathbf{G}+0.05 \mathbf{A}_{22}\right)^{-1}-\omega \mathbf{A}_{22}^{-1}
\end{array}\right],
$$

where $\mathbf{G}$ is the genomic relationship matrix [calculated using the first method presented in VanRaden (2008) and the observed allele frequencies], $\mathbf{A}$ is the pedigreebased relationship matrix (considering animals up to 10 generations back and accounting for inbreeding coefficients), and $\mathbf{A}_{22}^{-1}$ is the inverse of the section of $\mathbf{A}$ related to the genotyped animals. To make $\mathbf{A}$ and $\mathbf{G}$ more compatible, the optimal values for the scaling factors $(\tau$ and $\omega$ ) reported by Oliveira et al. (2019a), using the same populations, were used in this study. The values used for $\tau$ and $\omega$ are summarized in Supplemental Table S1 (https://doi.org/10.3168/jds.2019 -16821). Solutions of the mixed model equations were 
obtained using the BLUP90IOD software (Misztal et al., 2002, 2014), with a modified preconditioner for high-order multiple-trait RRM (Ignacio Aguilar, Instituto Nacional de Investigacion Agropecuaria, Canelones, Uruguay, personal communication). Prediction reliability and bias of breeding values for each trait, lactation, and breed, as well as complete description of the statistical models used in this study are detailed in Oliveira et al. (2019a).

Derivation of SNP Effects from Additive Random Regression Coefficients. The SNP solutions for the random regression coefficients were calculated using postGSf90 software (Aguilar et al., 2014). In summary, the postGSf90 software back-solves the additive genomic random regression coefficients (i.e., the GEBV for the additive random regression coefficients) to SNP effects. In a simple way, the back-solving process can be briefly described, for each trait, lactation, and breed, as follows (Wang et al., 2014):

$$
\hat{\mathbf{u}}_{c}=\mathbf{M}^{\prime}\left[\mathbf{M M}^{\prime}\right]^{-1} \widehat{\mathbf{G E B V}}_{c},
$$

where $\hat{\mathbf{u}}_{c}$ is the vector of estimated SNP solutions for the $c$ th random regression coefficient; $\mathbf{M}$ is the matrix that contains the centered genotypes (i.e., 1, 0, and -1 representing $A A, A a$, and $a a$, respectively), and $\overline{\mathbf{G E B V}}_{c}$ is the vector of GEBV for the cth random regression coefficient estimated by the ssGBLUP, which contains the $c$ th random regression coefficient from all genotyped animals.

Thereafter, the SNP solutions for all random regression coefficients $(c=1,2, \ldots, 5)$ of the same SNP $k$ were combined into a vector $\left(\hat{\mathbf{u}}_{k}=\left[\hat{\mathrm{u}}_{k_{1}} \hat{\mathrm{u}}_{k_{2}} \hat{\mathrm{u}}_{k_{3}} \hat{\mathrm{u}}_{k_{4}} \hat{\mathrm{u}}_{k_{5}}\right]^{\prime}\right)$, and used to estimate the SNP effects for all DIM (from 5 to $305 \mathrm{~d}$ ) as $\widehat{\mathbf{S N P}}_{k}=\mathbf{T} \hat{\mathbf{u}}_{k}$, where $\widehat{\mathbf{S N P}}_{k}$ is the vector that contains the SNP effects estimated for every DIM of the $k$ th SNP, $\mathbf{T}$ is a matrix of covariates for each DIM, associated with the Legendre orthogonal polynomials, and $\hat{\mathbf{u}}_{k}$ is the vector of SNP solutions for all random regression coefficients related to the $k$ th SNP.

Selection of Relevant SNP and Cluster Analyses. The SNP were selected for further investigation based on the magnitude of their effects. In this context, the SNP were ranked according to the magnitude of their daily effects (considering all DIM in the same rank), for each trait, lactation, and breed. The top $1 \%$ of SNP that showed a high magnitude of SNP effect in at least one DIM were selected as relevant SNP to be further investigated. The strategy for selecting the top $1 \%$ SNP has been implemented in several GWAS (Silva et al., 2014; Abdalla et al., 2016; Mastrangelo et al.,
2018), and seems to be sufficient to show changes in SNP effects over time between breeds.

To facilitate the visualization of results and posterior discussion, the SNP selected as relevant were clustered according to the trajectory of their SNP effects over time. Therefore, an algorithm was created in R (R Development Core Team, 2016) to assign each SNP to 1 of 5 pre-established clusters $(\mathbf{C}$; defined in preliminary analysis based on graphical inspection and biological knowledge of the traits; results not shown): $\mathrm{C} 1=$ constant SNP effect over time; C2 $=$ SNP effect increases over time; C3 = SNP effect decreases over time; C4 $=\mathrm{SNP}$ effect increases in the middle of lactation; and C5 $=$ SNP effect decreases in the middle of lactation. In brief, the created algorithm estimates the average of the daily SNP effect for 3 different lactation stages: (1) from 5 to 95 DIM; (2) from 96 to 215 DIM; and (3) from 216 to 305 DIM, as previously defined in Oliveira et al. (2019b), and then assigns the SNP to their most likely cluster based on the pattern of those averages. Averages that did not differ by more than $10 \%$ from one to another lactation stage were considered as constant over time. No significance tests were performed on these differences, because the estimated pattern of the lactation curve depends on the combination of all Legendre coefficients, making the test of individual coefficients not very useful.

To describe the differences among clusters, the average of the coefficient of variation (CV) was estimated for each cluster. The CV of the $k$ th SNP was calculated as follows:

$$
\mathrm{CV}_{k}(\%)=\frac{\mathrm{s}_{k}}{\overline{\mathrm{X}}_{k}} \times 100
$$

where $\mathrm{s}_{k}$ is the standard deviation for the $k$ th SNP over time, and $\overline{\mathrm{X}}_{k}$ is the $k$ th SNP mean.

\section{Gene Identification: Gene Mapping, Overrepresentation Analysis, and Candidate Genes}

Positional candidate genes were mapped using the Biomart tool (Kinsella et al., 2011) embedded in the Ensembl Genes database version 94 (http://useast .ensembl.org/index.html), using the bovine genome UMD 3.1 as the reference genome. Genes located within $\pm 250 \mathrm{~kb}$ from the location of the selected SNP were used in the overrepresentation analysis (ORA).

The ORA was performed using the Medical Subject Headings (MeSH) vocabulary to retrieve annotations that appear more frequently in a selected gene group relative to their occurrence by chance in a set of refer- 
ence genes (Nelson et al., 2004). The statistical significance $(P$-value) of this overrepresentation analysis was assessed by a hypergeometric test (Adams and Skopek, 1987):

$$
P=\sum_{i=k}^{\min (M, n)} \frac{\left(\begin{array}{c}
M \\
i
\end{array}\right)\left(\begin{array}{c}
N-M \\
n-i
\end{array}\right)}{\left(\begin{array}{c}
N \\
n
\end{array}\right)}
$$

where $N$ is the total number of genes that were analyzed for each trait (reference genes), $M$ is the total number of selected genes, $n$ is the total number of genes in the MeSH term under study, $k$ is the number of selected genes that belong to the MeSH term under study, and $\left(\begin{array}{l}y \\ x\end{array}\right)=\frac{y !}{x !}(y-x)$ ! is the binomial coefficient. To increase the power of test, all lactations from the same trait and breed were analyzed together in the ORA. The ORA was performed using the MeSH ORA tool (Tsuyuzaki et al., 2015), available in the Bioconductor package of the $\mathrm{R}$ software ( $\mathrm{R}$ Development Core Team, 2016).

Genes retrieved from significant $(P<0.01) \mathrm{MeSH}$ terms related to milk production traits were considered candidate genes for the traits, lactations, and breeds that they were identified. To understand the biological processes related to the studied traits and to define the most likely functional candidate genes, complete gene functions were obtained from the National Center for Biotechnology Information database (NCBI; www .ncbi.nlm.nih.gov/gene/) and Animal QTL Database (QTLdb; www.animalgenome.org/cgi-bin/QTLdb/ BT/index).

\section{RESULTS AND DISCUSSION}

\section{Selection of the Most Relevant SNP and Cluster Analysis}

The number of selected SNP, their average SNP effects, and average of CV estimated for each cluster are shown in Figure 1 for all traits, lactations, and breeds. A total of 381,407 , and $345 \mathrm{SNP}$ were selected as the most relevant (top 1\%) for each trait/lactation of the Ayrshire, Holstein, and Jersey breeds, respectively. In general, most SNP selected for MY, FY, and PY increased the magnitude of their effects over time (i.e., most SNP were clustered in C2) for all breeds. In contrast, for SCS, most selected SNP decreased the magnitude of their effects over time (i.e., most SNP were clustered in C3), especially for the Holstein and Jersey breeds, which might coincide with a higher prevalence of mastitis in early lactation for those breeds (Dego and Tareke, 2003). No SNP whose magnitude of effect decreased in the middle of lactation (C5) were found, for any of the traits, lactations, or breeds. In addition, no SNPs whose magnitude of effect increased in the middle of lactation (C4) were found for FY in the Ayrshire and Jersey breeds, or for SCS in the first lactation of all breeds.

Except for SCS in the first lactation of all breeds and FY in the first lactation of the Holstein breed, only a few SNP were found to have approximately constant effects over DIM (Figure 1). These results, combined with the different trajectory of SNP effects over time shown by the majority of SNP, suggest a differential phenotypic effect over time, which is in agreement with Strucken et al. (2011). For all traits, the average SNP effect was higher for Holstein than for the Ayrshire and Jersey breeds, which is likely due to the higher average MY in Holstein (i.e., scale effect). These findings are in agreement with Oliveira et al. (2019b), who reported genomic windows with a higher proportion of the explained genetic variance in the Holstein breed compared with the Ayrshire and Jersey breeds, and with Pryce et al. (2010), who found that the average variation explained by the significant SNP was higher in Holstein than in Jersey. Considering the average effects across selected SNP for all lactations, a single SNP changed the daily MY, FY, PY, and SCS by approximately $12.4 \mathrm{~g}, 0.4 \mathrm{~g}, 0.4 \mathrm{~g}$, and 1.4 , respectively, in the Ayrshire breed; by $39.4 \mathrm{~g}, 1.7 \mathrm{~g}, 1.0 \mathrm{~g}$, and 7.8, respectively, in the Holstein breed; and by $7.4 \mathrm{~g}, 0.4$ $\mathrm{g}, 0.2 \mathrm{~g}$, and 0.9, respectively, in the Jersey breed. For instance, this means that the QTL associated with an average SNP would be responsible for about $0.50 \mathrm{~kg}$ (i.e., $1.7 \mathrm{~g} \times 301$ ) of FY in one lactation of the Holstein breed, for example. This is in agreement with Strucken et al. (2012), when studying German Holstein Friesian cows, who concluded that one marker could change overall FY by approximately $0.46 \mathrm{~kg}$.

Especially for MY in the Holstein breed, the average SNP effect was higher in C2 for the first lactation, and in $\mathrm{C} 4$ for the second and third lactations, compared with the other clusters (Figure 1). This finding suggests that some genomic regions with a large effect in MY have an increasing effect over DIM in the first lactation, and higher effects in the middle of lactation in the second and third lactations. Thus, genomic regions with large effects in MY seem to have higher persistency in their SNP effect in the first lactation than in the second and third lactations, which could be related to the lower lactation peak and higher lactation persistency found in the first lactation of the Holstein breed compared with later lactations (Stanton et al., 1992; Márquez et al., 2016). Similar results were found for 


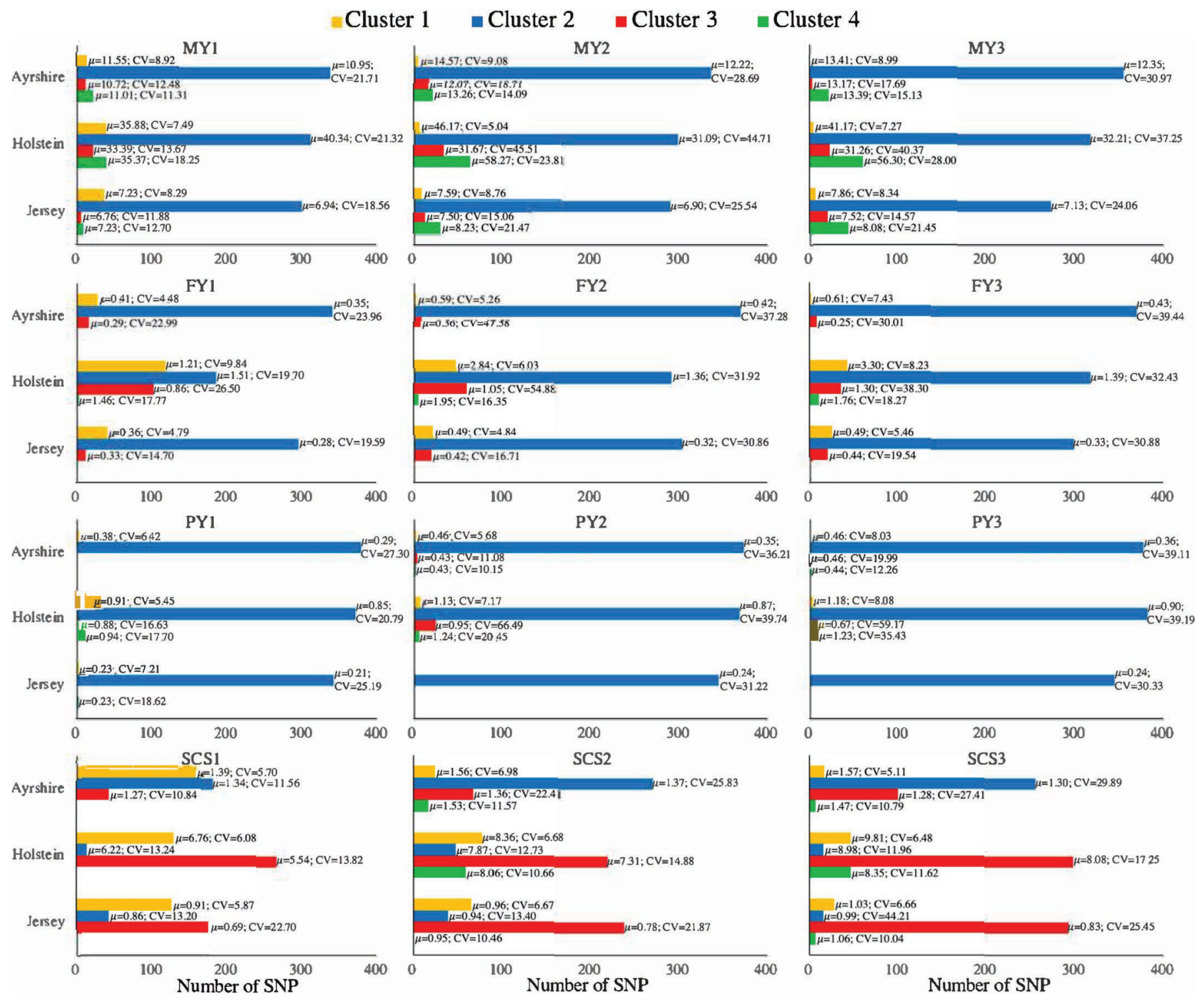

Figure 1. Number of selected SNP, average $(\mu)$ of their effect, and coefficient of variation $(\mathrm{CV})$ in percentage, estimated in each cluster for all traits and lactations of Ayrshire, Holstein, and Jersey breeds. Cluster $1=$ constant SNP effect over time; cluster $2=$ SNP effect increases over time; cluster 3 = SNP effect decreases over time; and cluster 4 = SNP effect increases in the middle of lactation. Traits: milk (MY1, MY2, MY3), fat (FY1, FY2, FY3), and protein (PY1, PY2, PY3) yields, and SCS (SCS1, SCS2, SCS3) in the first, second, and third lactations, respectively.

FY in the Holstein breed, whose higher average SNP effect was observed in $\mathrm{C} 1$ compared with the other SNP clusters, especially for the second and third lactations (Figure 1). Similar average SNP effects were estimated among different clusters for all other traits and breeds. As expected, higher CV were estimated in C2 and C3 than in the other clusters (Figure 1). The trajectory of SNP effects over DIM estimated for the top 10 SNP of each cluster for each trait and lactation are shown in Supplemental Figures S2, S3, and S4 (https://doi.org/ 10.3168/jds.2019-16821), for the Ayrshire, Holstein, and Jersey breeds, respectively.

\section{ORA and Candidate Genes}

The ORA is used to retrieve genes that appear more frequently in a selected group relative to their occurrence by chance (Nelson et al., 2004). Currently, several GWAS have used ORA to reduce the number of candidate genes and, consequently, to find the most likely candidate genes related to traits of interest in various species, including cattle, swine, horses, and chicken (Morota et al., 2015, 2016; Oliveira et al., 2019b). In this study, the ORA reduced the number of candidate genes, which consequently facilitated the interpretation 


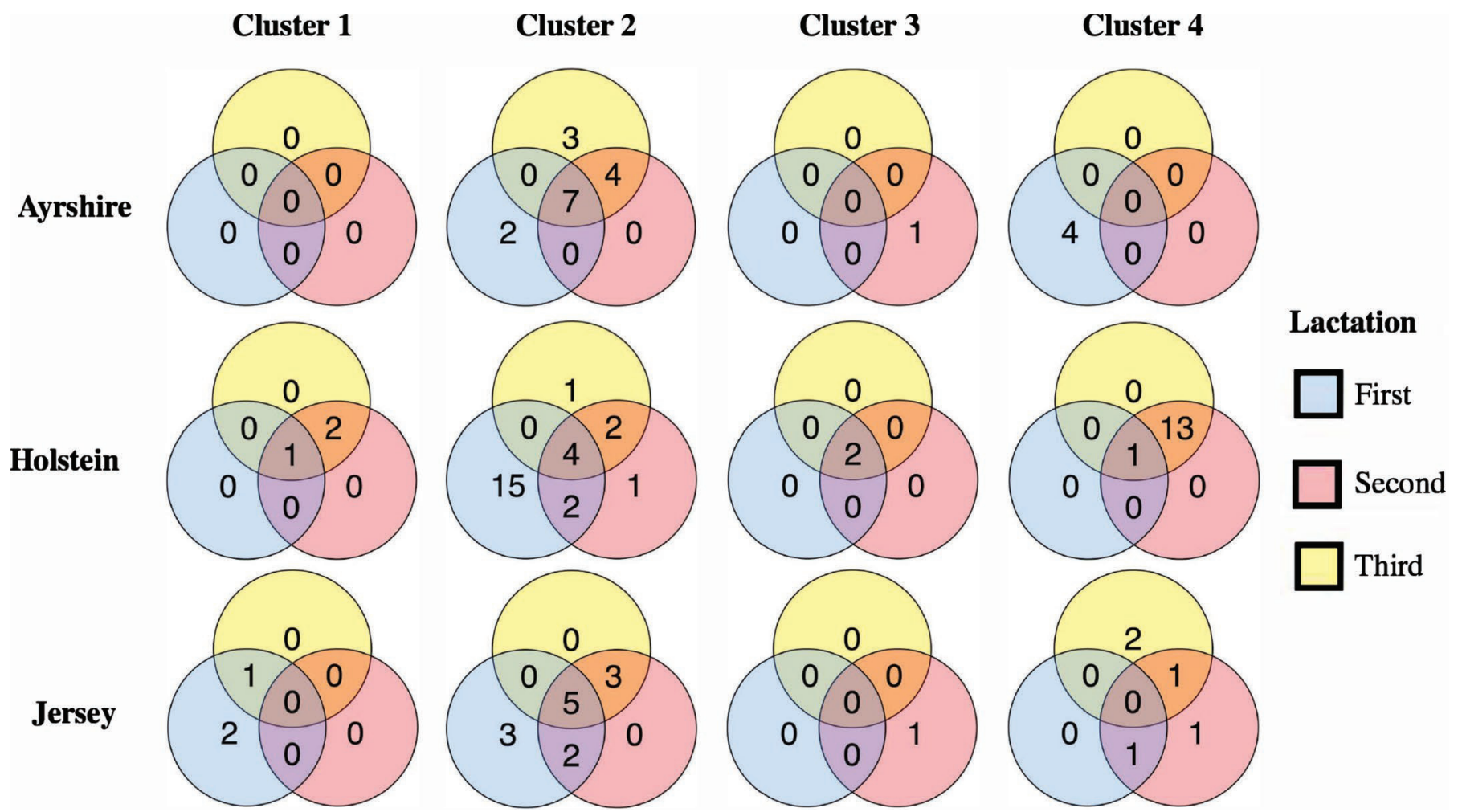

Figure 2. Number of common candidate genes for milk yield in the different lactations of Ayrshire, Holstein, and Jersey breeds. Cluster 1 $=$ constant SNP effect over time; cluster $2=$ SNP effect increases over time; cluster $3=$ SNP effect decreases over time; and cluster $4=$ SNP effect increases in the middle of lactation.

of the results. The number of candidate genes found in common after the ORA for MY, FY, PY, and SCS in different lactations is shown in Figures 2, 3, 4, and 5, respectively. A summary of the total number of candidate genes found for each cluster is given in Supplemental Table S2 (https://doi.org/10.3168/jds.2019-16821).

As expected, due to the number of phenotypic records available and SNP selected for each breed (Table 1 ), the number of candidate genes identified was, in general, higher for the Holstein breed, followed by the Ayrshire and Jersey breeds, respectively. With the exception of SCS for the Holstein and Jersey breeds, the highest number of candidate genes was found in $\mathrm{C} 2$ for all traits and breeds, which suggests that the majority of genes related to milk-related traits have the phenotypic effect increased over DIM. In general, the same candidate gene was not found in more than one cluster, which suggests that SNP associated with the same candidate gene have similar SNP effect patterns over time, and that the method used to cluster the SNPs was efficient. In accordance with Oliveira et al. (2019b), similar genes were found across different lactations for the same trait of a same breed (Figures 2 to 5 ). For some of the candidate genes, the suggested pattern of phenotypic effect changed among lactations (i.e., some candidate genes were found in different clusters in different lactations; Supplemental Tables S3 to S6; https: //doi.org/10.3168/jds.2019-16821). Among lactations, candidate genes (and the suggested phenotypic effect over time) identified for the second and third lactations were more similar to each other than to those identified for the first lactation. This may be related to the fact that the activity level of different genes that contribute to milk-related traits in different lactations depends on the metabolic changes happening in the individual (Strucken et al., 2011), and in the first lactation, cows are still growing; that is, the mammary gland and digestive tract are under development (Taylor et al., 2003).

The number of candidate genes found in common for each breed is shown in Figure 6. Similar to the findings reported by Oliveira et al. (2019b), a different set of candidate genes was identified for each breed. From the different sets of candidate genes found, only 2 were found across all 3 breeds. Considering only the candidate genes identified in more than one breed, they were more similar between Ayrshire and Holstein breeds. This reinforces the hypothesis that differences exist in the underlying lactation biology and genes associated with milk-related traits across breeds or populations. Detailed information regarding the candidate genes 


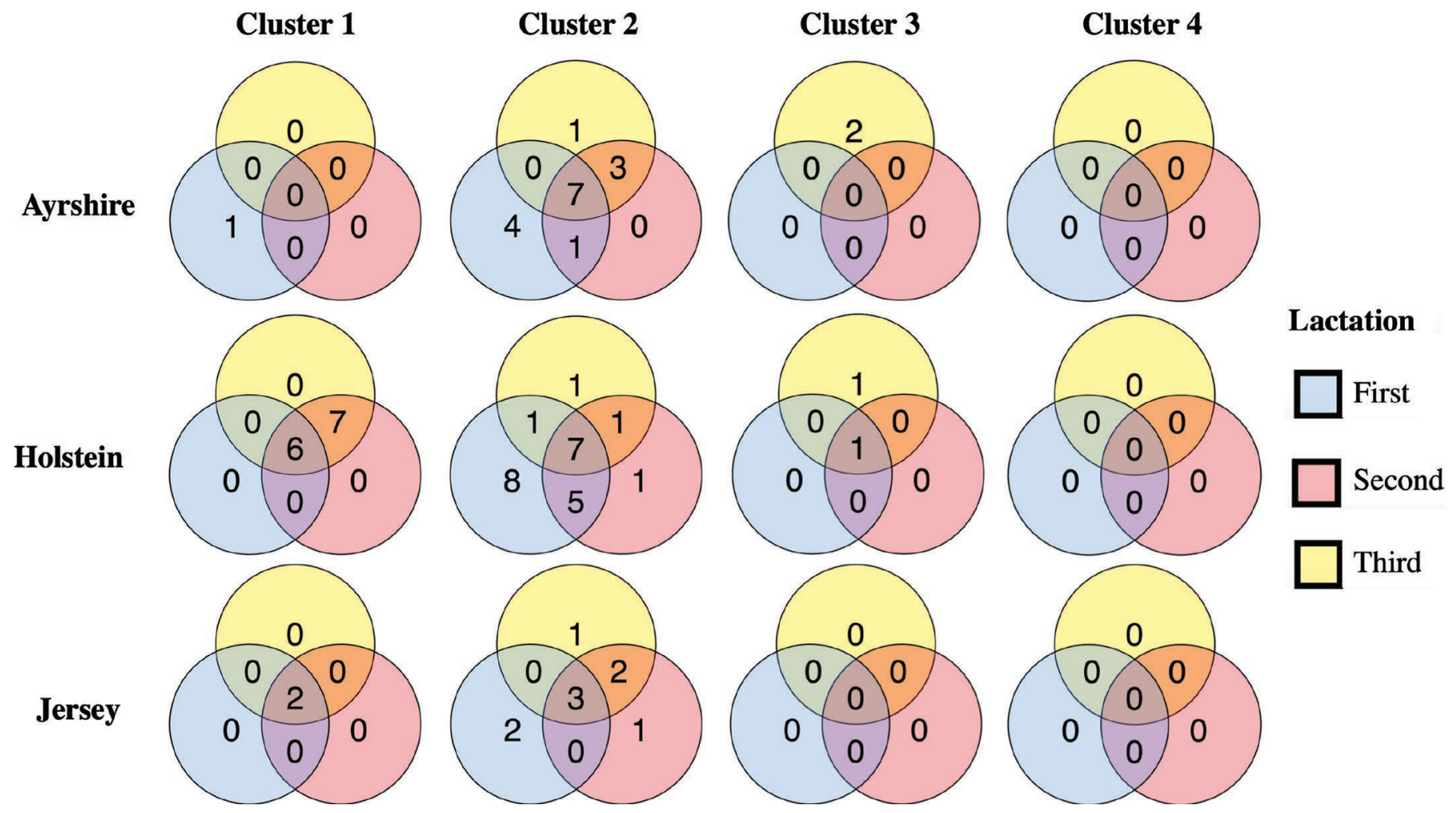

Figure 3. Number of common candidate genes for fat yield in the different lactations of Ayrshire, Holstein, and Jersey breeds. Cluster 1 $=$ constant SNP effect over time; cluster $2=\mathrm{SNP}$ effect increases over time; cluster $3=\mathrm{SNP}$ effect decreases over time; and cluster $4=\mathrm{SNP}$ effect increases in the middle of lactation.

mapped through Ensembl for the SNP selected in each cluster after the ORA is given in Supplemental Tables S3, S4, S5, and S6 (https://doi.org/10.3168/jds.2019 -16821), for MY, FY, PY, and SCS, respectively. Only selected candidate genes will be discussed in detail in this paper.

\section{Candidate Genes for MY}

The number of candidate genes in common was higher between Ayrshire and Holstein breeds (Figure 6). Among the candidate genes in commom for MY were ACO2, BOP1, DGAT1, FBXL6, IGLL1, and SLC5A1 (for Ayrshire and Holstein), KPNA7 (for Ayrshire and Jersey), GNG12 and SLC25A4 (for Holstein and Jersey), and $C O L 4 A 3$ (for all breeds). However, only $A C O 2, K P N A \%$, and SLC25A4 were found in the same clusters for the mentioned breeds. The BOP1, DGAT1, $F B X L 6, I G L L 1$, and $S L C 5 A 1$ genes were grouped in $\mathrm{C} 2$ for Ayrshire (all lactations) and Holstein (only in the first lactation). For the second and third lactations of the Holstein breed, these candidate genes were grouped in either $\mathrm{C} 1$ or $\mathrm{C} 4$. The GNG12 gene was found in $\mathrm{C} 3$ for the Holstein breed and in $\mathrm{C} 2$ for the Jersey breed. In addition, $C O L 4 A 3$ was found in $\mathrm{C} 2$ for the Ayrshire and $\mathrm{C} 1$ for the Holstein and Jersey breeds. Details regarding the candidate genes found in each cluster for MY are shown in Supplemental Table S3 (https://doi .org/10.3168/jds.2019-16821).

No candidate genes with constant suggested effect over DIM (i.e., candidate genes associated with SNP clustered in $\mathrm{C} 1$ ) were found for MY in the Ayrshire breed. Genes such as IGFBP3, ACO2, ANGPTL4, FASN, CCL28, PRLR, and BTN1A1 showed an increasing effect over time for all 3 lactations. For instance, BTN1A1 has been linked to the secretion of milk lipid droplets because it is highly expressed in the mammary epithelium during lactation (Jeong et al., 2009). The CCL28 gene has been reported to play a role in lactation persistence in Canadian Holstein cattle (Do et al., 2017), which may explain its increased effect over time here for the Ayrshire breed. As discussed by Tong et al. (2018), milking frequency affects lactation persistency, expression of the PRL receptor $(P R L R)$, and the milk response to prolactin inhibition (Bernier-Dodier et al., 2011; Lacasse et al., 2011). Therefore, it is possible that some factors modulating milk production are affecting prolactin secretion or the responsiveness of the mammary gland to this hormone (Tong et al., 2018). 


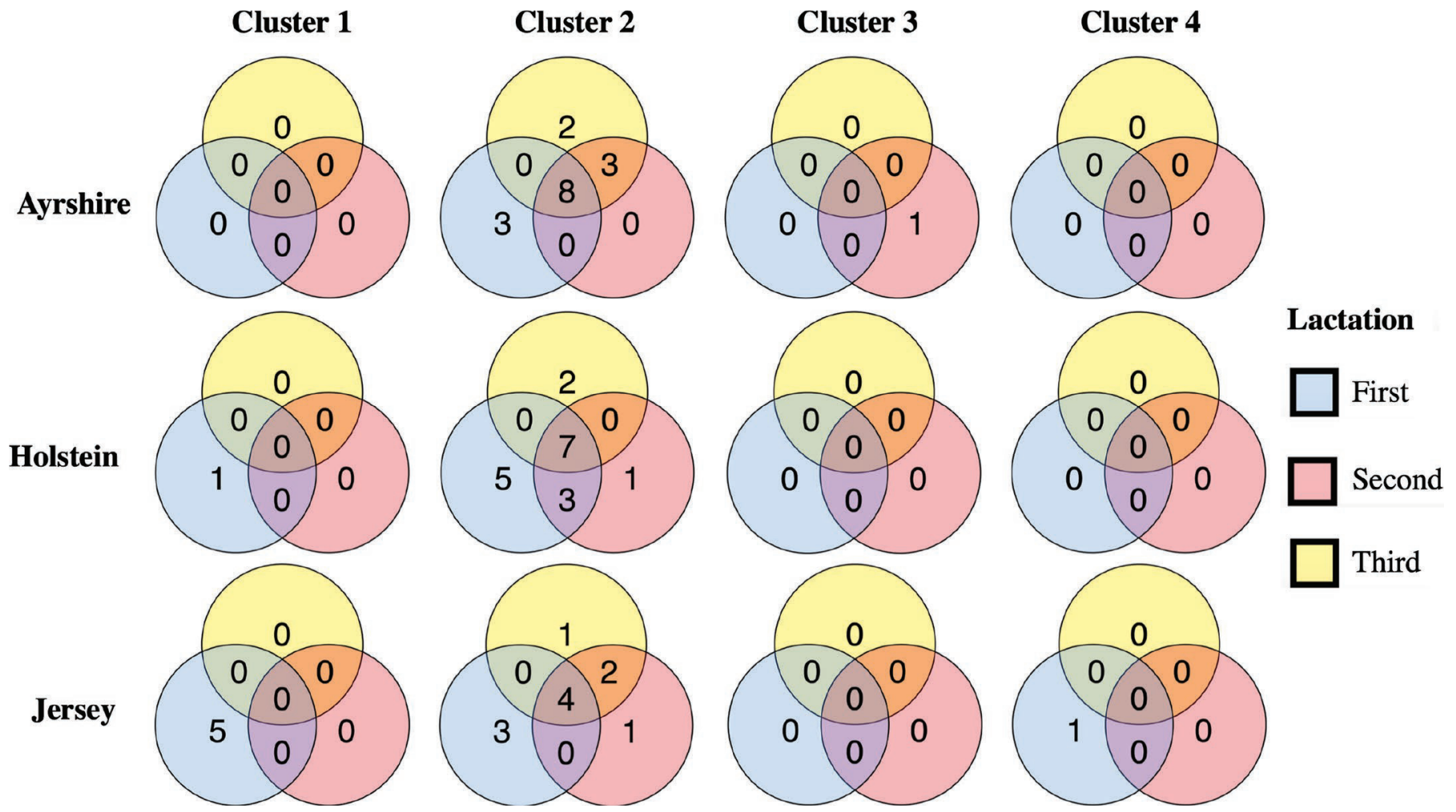

Figure 4. Number of common candidate genes for protein yield in the different lactations of Ayrshire, Holstein, and Jersey breeds. Cluster $1=$ constant SNP effect over time; cluster $2=$ SNP effect increases over time; cluster $3=$ SNP effect decreases over time; and cluster $4=$ SNP effect increases in the middle of lactation.

The genes MAP2, DGAT1, IGLL1, and SLC5A1 showed an increasing effect over DIM (C2) and were suggested as candidate genes only for the second and third lactations of the Ayrshire breed. These genes are well known to affect MY and other milk-related traits (Nilsen et al., 2009; Huang et al., 2012). Cerri et al. (2012), investigating the effects of lactation and pregnancy on endometrial gene expression on day 17 of the estrous cycle and pregnancy, reported that IGLL1 was upregulated by lactation. The casein group (i.e., CSN1S1, CSN1S2, and CSN3 genes) was suggested as a candidate with increased phenotypic effect in the middle of lactation, only in the first lactation. Interestingly, CSN1S1 was suggested to have a decreasing effect over DIM in the second lactation. Strucken et al. (2012) reported that the largest effects for the casein genes occurred at the beginning of the lactation, but they did not find statistical significance for MY. In addition, Strucken et al. (2012), studying how the influence of genomic regions changes during the first 60 DIM in German Holstein Friesian cattle, showed that DGAT1 had increasing effects for MY.

Some genes were identified to be affecting all production traits (i.e., MY, FY, and PY) in all lactations of Ayrshire, with differential phenotypic effect patterns, such as $A N G P T L 4$, which is known to play an important role in lipid metabolism. Wang et al. (2018) investigated variations of serum ANGPTL4 in periparturient and early lactation dairy cows and reported that serum ANGPTL4 concentrations peaked at parturition, and declined rapidly over the following $2 \mathrm{wk}$, indicating that energy balance changes associated with parturition contributed significantly to this effect. Koltes and Spurlock (2012) reported that the abundance of $A N$ GPTL4 mRNA expression increased 2- to 6-fold with declining energy balance. According to those authors, the consistency and magnitude of the increase in $A N G$ PTL4 mRNA across multiple models of altered energy balance identifies it as an adipokine that is uniquely responsive to changes in energy balance in the lactating dairy cow. In our study, depending on the trait, this gene was clustered in different groups (e.g., C1 or C2).

For the Holstein breed, our results suggested that COL4A3 has a constant effect over DIM for all 3 lactations. In addition, IGLL1 and SLC5A1 showed a constant effect over DIM but only for the second and third lactations. The candidate genes GNG12 and TNFRSF1A were suggested to have a decreasing effect over DIM for all 3 lactations. Interestingly, genes on BTA14 are well known for their effects in MY; for 


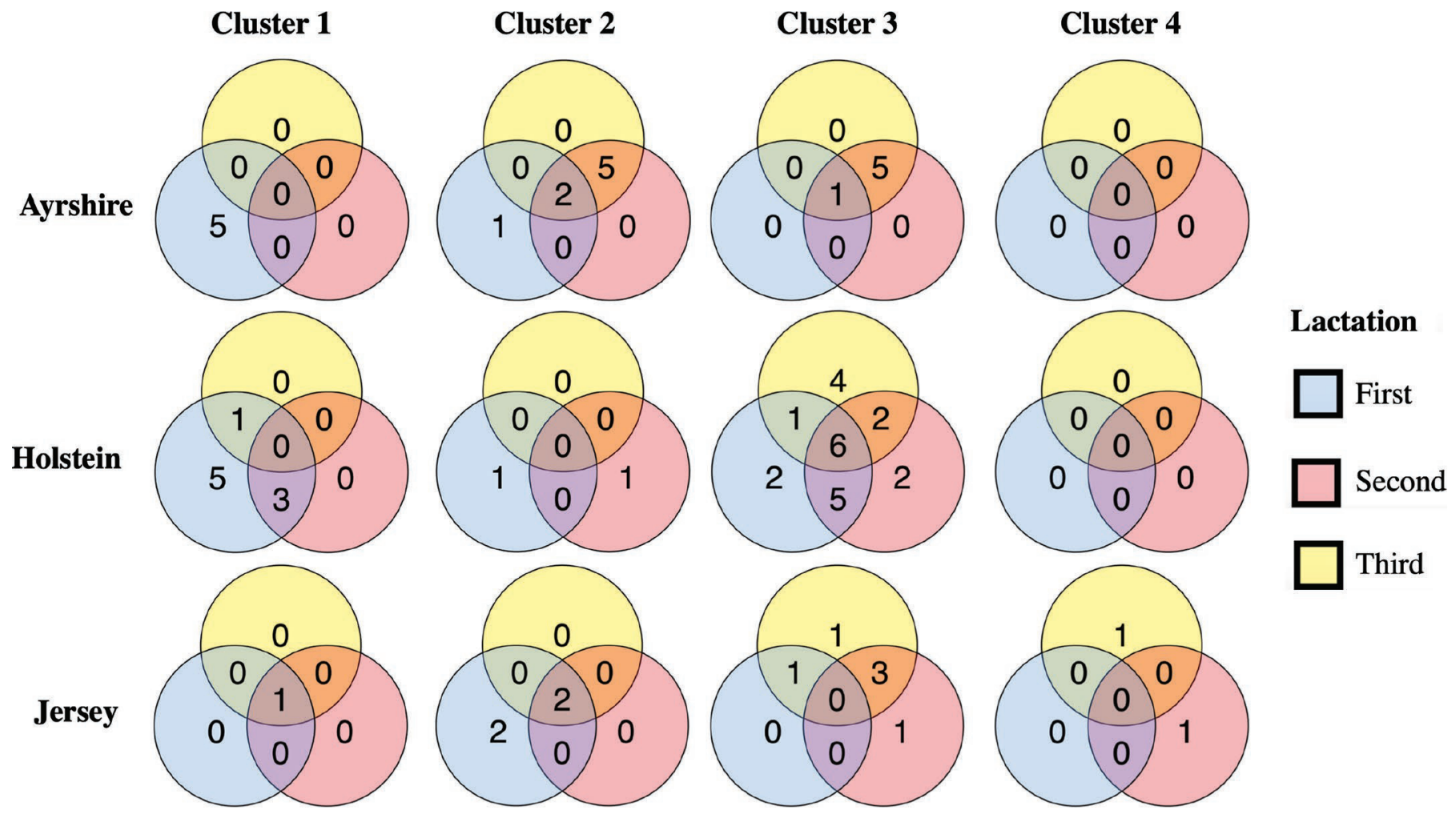

Figure 5. Number of common candidate genes for SCS in the different lactations of Ayrshire, Holstein, and Jersey breeds. Cluster $1=$ constant SNP effect over time; cluster $2=$ SNP effect increases over time; cluster $3=$ SNP effect decreases over time; and cluster $4=$ SNP effect increases in the middle of lactation.

example, BOP1, CPSF1, CYHR1, DGAT1, EEF1D, FBXL6, FOXH1, LRRC24, PTK2, RECQL4, TONSL, TRAPPC9, and VPS28 had increasing effects over DIM in the first lactation and a higher effect in the middle of lactation in the second and third lactations. This suggests that the pattern of phenotypic effect for these genes also changes across lactations, even though they remain important in all lactations. The EEF1D gene has previously been associated with fat percentage (Jiang et al., 2010), which is a trait dependent on the level of MY and FY across lactation. The importance of this gene for various milk traits and breeds highlights its importance in lactation biology. In addition, the different pattern of phenotypic effect suggested for genes on BTA14 may explain the higher average SNP effect in $\mathrm{C} 2$ for the first lactation and in $\mathrm{C} 4$ for the second and third lactations. Differences compared with the conclusions presented by Strucken et al. (2012) for the DGAT1 gene are probably because of the short period studied by those authors and the use of MY averaged over the first 3 lactations. Thus, Strucken et al. (2012) could not observe suggested decrease in phenotypic expression after the middle of lactation for the second and third lactations.
Wang et al. (2015a) investigated the expression pattern of the clock circadian regulator network and selected metabolic genes simultaneously in mammary gland, liver, and subcutaneous adipose tissue to better understand the transition from late gestation to early lactation. The authors reported that the expression of PPARA was lower at $-10 \mathrm{~d}$ but increased after parturition. However, Schäff et al. (2013) reported that PPARA expression decreased continuously after parturition, whereas we observed an effect increase in the middle of lactation (C4) for Holstein.

For the Jersey breed, the SLC34A2, STAT5A, IG$F 1 R, K P N A 7$, and SLC5A2 genes showed increasing effects over DIM in all 3 lactations (C2). The STAT5A gene, a member of the JAK-STAT signaling pathway, has been associated with proliferation, secretory differentiation, and survival of mammary epithelial cells and milk synthesis (Furth et al., 2011; Liu et al., 2012; Ao et al., 2015). Additionally, STAT5A mediates the pathway to regulate milk protein synthesis, mammary gland epithelial cell differentiation (Faraci-Orf et al., 2006; Buser et al., 2007), and mastitis susceptibility (Usman et al., 2014). Interestingly, the pattern of phenotypic effect suggested for $A C T B$ changed completely 

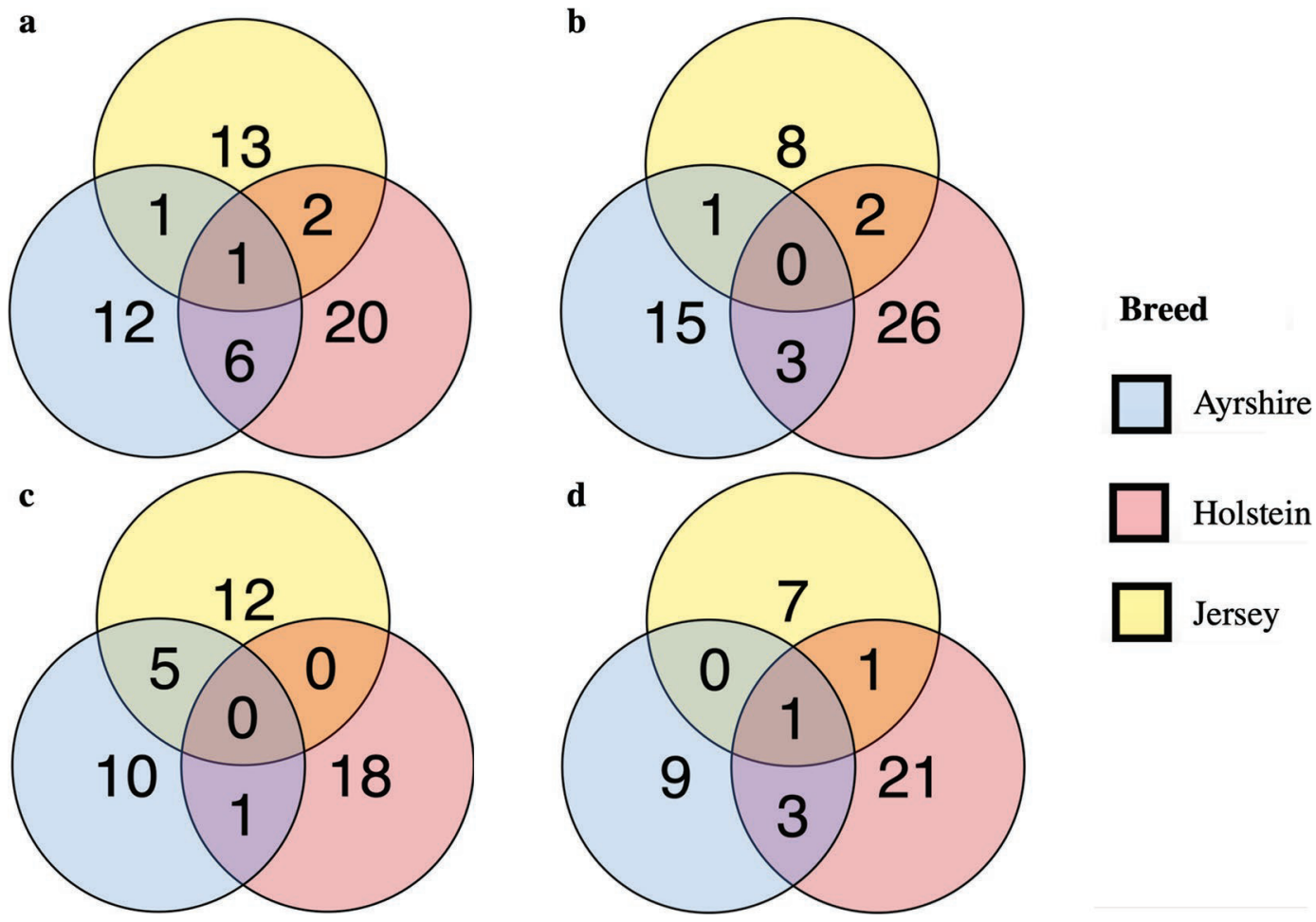

Figure 6. Number of common candidate genes in the different breeds for milk (a), fat (b), and protein (c) yields, and SCS (d).

among lactations, as it had a suggested constant effect over time in the first lactation (C1), a decreasing effect in the second lactation (C3), and a higher effect in the middle of lactation, in the third lactation (C4). The $I K B K B, N R G 1$, and $A N X A 11$ genes were suggested as candidate genes with increasing effect over time for the second and third lactations. In agreement with Oliveira et al. (2019b), no potential effect of DGAT1 gene was found for MY in the Jersey breed.

\section{Candidate Genes for FY}

No common candidate genes were identified among all 3 breeds (Figure 6). Among the candidate genes in common for FY between 2 breeds were ACO2, PTK2, and TRAPPC9 (for Ayrshire and Holstein); KPNA 7 (for Ayrshire and Jersey); and BOP1 and DGAT1 (for Holstein and Jersey). In this context, ACO2, KPNA7, $B O P 1$, and DGAT1 were found in the same clusters for the mentioned breeds. However, PTK2 and TRAPPC9 were grouped in $\mathrm{C} 2$ for the Ayrshire (found only in the first lactation) and C1 for the Holstein breed (all lactations). Details regarding the candidate genes found in each cluster for FY are shown in Supplemental Table S4 (https://doi.org/10.3168/jds.2019-16821).

The CSN1S1 and PTK2 genes were suggested as candidate genes only for the first lactation of the Ayr- shire breed, and they had suggested constant $(\mathrm{C} 1)$ and increasing (C2) effects over DIM, respectively. The ACP6, IGFBP3, ANGPTL4, SLC5A1, DCXR, FASN, and PYCR1 genes had increasing effects over DIM (C2), for all 3 lactations. Bionaz and Loor (2008) studied mammary tissue mRNA expression across changes in physiological state, including different lactation stages, and they reported that FASN is associated with fatty acid synthesis and desaturation. Moreover, these authors reported that the peak expression of FASN was around 60 DIM.

For the Holstein breed, the BOP1, DGAT1, FBXL6, OPLAH, PTK2, and TRAPPC9 genes had constant effect over DIM (C1) for all 3 lactations. However, as suggested by the average SNP effect estimated in the clusters, some important genes on BTA14 had different phenotypic effect patterns in the first lactation compared with second and third lactations. Those genes were CPSF1, CYHR1, FOXH1, LRRC24, RECQL4, SLC39A4, TONSL, and VPS28, and they had an increasing effect over DIM in the first lactation and a constant effect in the second and third lactations. For instance, CPSF1 and CYHR1 have been reported to be associated with milk fat components (Buitenhuis et al., 2014; Jiang et al., 2014; Nayeri et al., 2016); FOXH1 has also been linked to milk-related traits (Nayeri et al., 2016). The ADIPOR2 gene showed an 
increasing effect in the first and second lactations and a decreasing effect over DIM in the third lactation. Weber et al. (2016) reported that ADIPOR2 expression changed from late gestation to early lactation. Ohtani et al. (2011) investigated the expression of ADIPOR2 in various bovine tissues and mammary glands among different lactation stages, and the effects of lactogenic hormones (insulin, dexamethasone, and prolactin) and growth hormone in cultured bovine mammary epithelial cells (BMEC). They reported that in BMEC, lactogenic hormones and growth hormone upregulated ADIPOR2 mRNA expression. Loor et al. (2006) studied temporal gene expression profiles during the dry period and early lactation in liver of Holstein cows. They identified 85 genes with expression patterns that were affected by level of energy intake prepartum over time. Restricted energy intake prepartum resulted in more pronounced upregulation of genes with key functions in hepatic fatty acid oxidation that were also identified in our study (ADIPOR2), and ad libitum feeding upregulated several genes associated with liver triacylglycerol synthesis (DGAT1) and proinflammatory cytokines (TNFAIP3). However, in our study, TNFAIP3 was associated with SCS. Other well-known candidate genes were suggested to have the same phenotypic effect pattern over DIM in all 3 lactations, such as AGPAT3, APP, ACO2, DNTT, FAS, IFIT3, and IFIT5, which had an increasing effect over DIM, and EEF1D, which had a suggested decreasing effect over DIM for all 3 lactations.

Similar to results for Holstein, the BOP 1 and DGAT1 genes were suggested to have a constant effect over DIM for all 3 lactations in the Jersey breed. Those results corroborate with those of Oliveira et al. (2019b), which also reported the BOP1 and DGAT1 genes as being important along lactation for FY in Jersey. The SLC34A2, SLC25A11, and IKBKB genes were found to have increasing effects over DIM in all 3 lactations. In contrast, the IGFBP2 and FTO genes were suggested to have increasing effects over DIM only for the second and third lactations. Zielke et al. (2013) investigated the biological role of FTO (fat mass and obesity associated gene) on milk composition in German Holstein cattle. They reported that higher-frequency SNP alleles and haplotypes within the FTO gene increased FY and PY by up to 2.8 and $2.2 \mathrm{~kg}$ per lactation, respectively. According to those authors, the pleiotropic effects observed suggest a biological function on the usage of energy resources and the control of energy balance rather than directly affecting fat and protein synthesis. Clempson et al. (2012) reported that polymorphisms in IGFBP2 were associated with the circulating patterns of glucose, insulin, and BHB, particularly around second calving. Interestingly, for the Jersey breed, we observed that this gene was identified in second and third parities for FY. Clempson et al. (2012) also reported associations between the IGFBP2 SNP and 305-d yield in the first lactation, as well as trends of association with DIM in first and second lactations in UK dairy cows.

\section{Candidate Genes for PY}

Differently from the other traits, more candidate genes were in commom for PY between the Ayrshire and Jersey than for the Ayrshire and Holstein breeds (Figure 6). Among the candidate genes found were ACO2 (for Ayrshire and Holstein), and COL4A3, CSN1S1, NPC1, PDIA3, RPL37 (for Ayrshire and Jersey). In summary, the ACO2, COL4A3, NPC1, and PDIA3 candidate genes were found in the same clusters for the mentioned breeds. In contrast, CSN1S1 was grouped in $\mathrm{C} 2$ and $\mathrm{C} 3$ for the Ayrshire breed (in the first and second lactations, respectively), and $\mathrm{C} 1$ for the Jersey breed (all lactations). The RPL37 gene was grouped in $\mathrm{C} 2$ and $\mathrm{C} 4$, for the Ayrshire and Jersey breeds, respectively. Details regarding the candidate genes found in each cluster for PY are shown in Supplemental Table S5 (https://doi.org/10.3168/jds.2019-16821).

The majority of candidate genes found for PY were suggested to have an increasing effect over DIM. Specifically for the Ayrshire breed, IGFBP3, ACO2, ANGPTL4, IGLL1, SLC5A1, EIF1, FASN, and PDIA3 genes were suggested as candidate genes for all 3 lactations. Interestingly, CSN1S1 was suggested as a candidate gene with a decreasing effect over DIM for the second lactation. Strucken et al. (2012) found statistical significance in the decreasing gene expression of CSN1S1 over time for PY, when studying the first 60 DIM of German Holstein Friesian cattle.

For the Holstein breed, GNG12 was suggested as a candidate gene with constant effect over DIM, for the first lactation. The $A P P, A C O 2, P L C B 4$, and $B o L A$ genes were suggested to have an increasing effect over DIM for all 3 lactations. The bovine major histocompatibility complex $(B o L A)$ genes encode proteins involved in the presentation of extracellular antigens to $\mathrm{CD} 4^{+} \mathrm{T}$ cells (Ellis et al., 1999), and are known to have a significant role in the development of immunological response and disease resistance (Stear et al., 2001; Ellis and Codner, 2012). Various studies have associated the BoLA genes with clinical mastitis, SCS, and antibody-mediated and cell-mediated immune responses in Holstein cattle (Wu et al., 2010; Yoshida et al., 2012; Thompson-Crispi et al., 2014). Interestingly, we identified an association of BoLA with MY, PY and FY, but not with SCS. Pokorska et al. (2018) also identified a higher MY for a specific allele in Holstein cattle. The BOP1, DGAT1, EEF1D, FBXL6, and PTK2 genes were suggested as 
candidate genes only for the first lactation. In addition, it is important to notice that the AGPAT1, BMP5, and $C Y P 21$ genes were suggested as candidate genes for the first and second lactations, and that FAS, IFIT3, and IFIT5 were suggested as candidate genes for the second and third lactations; all had an increasing effect over DIM. Our findings regarding the potential pattern of phenotypic effect of the candidate genes identified for PY disagree with those reported by $\mathrm{Lu}$ and Bovenhuis (2019), in a recent study analyzing 1,829 Dutch Holstein first-parity cows. In that study, the authors used 4 different GWAS approaches to analyze PY, which included separate GWAS for specific lactation stages, and GWAS using repeatability models (assuming both SNP effects constant during lactation or genotype by lactation stage interaction); they concluded that there was no evidence that their effects changed during lactation.

For the Jersey breed, the casein group (i.e., $C S N 1 S 1$, CSN1S2, and CSN3 genes), STATH, and PRLR genes were identified as having a constant effect over DIM for the first lactation. The SLC34A2, TLR4, PDIA3, and $N P C 1$ genes were suggested as candidate genes with increasing effects over DIM, for all 3 lactations. The TLR 4 gene, which was identified to be important for MY and PY, had been previously associated with lactation persistency in Canadian Holstein bulls (Sharma et al., 2006), as well as MY, FY, and fat and protein percentage and other milk composition traits (Viale et al., 2017; Zhou et al., 2017). The IKBKB and NRG1 genes were found to have an increasing effect over DIM only for the second and third lactations. Interestingly, RPL37 was suggested to have a higher effect in the middle of lactation in the first lactation. The gene $M A P K 1$, which was identified for all 4 traits in this study, regulates milk protein synthesis (Lu et al., 2012).

\section{Candidate Genes for SCS}

Only a few candidate genes were identified in common for SCS between the breeds (Supplemental Table S6; https://doi.org/10.3168/jds.2019-16821). Among the important candidate genes identified for SCS in more than one breed were EEF1D, SNCA, TNFRSF1A (for Ayrshire and Holstein); $A B C G 2$ (for Holstein and Jersey); and TRAPPC9 (for all 3 breeds). Interestingly, all candidate genes identified for SCS were found in different clusters among the mentioned breeds. In this context, the $E E F 1 D$ gene was found either in $\mathrm{C} 1$ or $\mathrm{C} 2$ for the Ayrshire, and in C3 for the Holstein breed. The SNCA and TNFRSF1A genes were found in $\mathrm{C} 2$ for the Ayrshire, and in either $\mathrm{C} 1$ or C3 for the Holstein breed. The $A B C G 2$ gene was found in $\mathrm{C} 1$ or $\mathrm{C} 3$ for the Holstein and in $\mathrm{C} 4$ for the Jersey breed. The TRAPPC9 gene was found in $\mathrm{C} 1$ or $\mathrm{C} 3$ for the Ayrshire, $\mathrm{C} 1$ or $\mathrm{C} 2$ for the Holstein, and C2 or C3 for the Jersey breed. Details regarding the candidate genes found in each cluster for SCS are shown in Supplemental Table S6 (https://doi.org/10.3168/jds.2019-16821).

For Ayrshire, TUBB2B and SLC5A2 were suggested as candidate genes with increasing effect over DIM, for all lactations, whereas $A C T B$ gene was suggested as a candidate gene with decreasing effect over DIM, for all lactations. Interestingly, the $A C P 6, T N F A I P 3, C A P N 3$, and TRAPPC9 genes were suggested as candidate genes with constant effect in the first lactation and with decreasing effect in the second and third lactations. In the same way, the EEF1D gene was suggested as a candidate gene with constant effect in the first lactation, whereas it seemed to increase its effect in the second and third lactations.

For the Holstein breed, genes such as BOP1, DGAT1, EEF1D, FBXL6, C4BPA, and $C 4 B P B$ were suggested as candidate genes with higher effects in the middle of lactation, for all 3 lactations. However, although the TNFRSF1A and SNCA genes also seemed to have a higher effect in the middle of lactation for the second and third lactations, they had constant effects in the first lactation. The $A B C G 2, F A M 13 A$, and HTRA4 genes were suggested as candidate genes with constant effect in the first and second lactations and with higher effects in the middle of lactation for the third lactation. The ATP-binding cassette sub-family $\mathrm{G}$ member 2 (ABCG2) gene has been associated with various milk-related traits in Holstein and other dairy breeds, including milk production (Pausch et al., 2017), coagulation properties (Cecchinato et al., 2015), and fatty acid composition ( $\mathrm{Li}$ et al., 2016). In addition, various signature of selection studies have identified this gene as playing an important role in milk production traits (e.g., Rothammer et al., 2013; Zhao et al., 2015). Li et al. (2016) reported an association between FASN, $A B C G 2$, and $I G F 1$ on milk fatty acid composition. Wei et al. (2012) concluded that $A B C G 2$ plays an important role in mammary epithelial cell proliferation and that functional polymorphisms in this gene may influence the cellular compartment of the mammary gland and potentially milk production. As there is an inferred positive correlation between mammary cell numbers and milk production, mammary progenitor cells may be important in renewing damaged mammary cells during lactation (Capuco and Ellis, 2005), which could also explain its differential association with SCS during the lactation. Mani et al. (2009) investigated the differential expression and localization of lipid transporters in the bovine mammary gland during the pregnancy-lactation cycle and reported that $A B C G 2$ mRNA abundance was significantly increased after parturition and declined 
from the lactating to the nonlactating state in the bovine mammary gland. In accordance with this hypothesis, for the Holstein breed, $A B C G 2$ was identified in $\mathrm{C} 1$, whereas, for Jersey, it was clustered in $\mathrm{C} 4$ (higher effect in the middle of lactation). Do et al. (2017) suggested the association of this gene with lactation persistence. The NRG1 gene has been strongly correlated with the progression of Staphylococcus aureus subclinical mastitis (Song et al., 2016). The SOCS3 gene, identified for SCS in our study, was previously thought to have a primary role in apoptosis and tissue remodeling during involution through programmed cell death and tissue remodeling, initiated after the termination of lactation (Sutherland et al., 2007). Arun et al. (2015) reported that the levels of SOCS3 expression increased from pregnancy to involution.

For the Jersey breed, the SLC25A4 gene was suggested to have a constant effect and the SLC34A2 and PRLR genes were suggested to have increasing effects over DIM, for all 3 lactations. Prolactin receptor $(P R L R)$, known to be associated with production traits and SCS (Meredith et al., 2012), was found to be downregulated in bovine mammary epithelial cells infected with Staphylococcus aureus (Lara-Zárate et al., 2011), as well as in bovine hepatic tissue following intramammary injection of Escherichia coli LPS to simulate mastitis infection (Jiang et al., 2008). Prolactin was found to be significantly increased in udder quarters with high SCS and chronic mastitis (Boutet et al., 2007). In addition, $P R L R$ has been suggested to be associated with mammary gland epithelium development and mammary gland alveolus development and milk production traits (Lü et al., 2011; Viale et al., 2017; Marete et al., 2018). The COL4A3 and TRAPPC9 genes were suggested as candidate genes with increasing effects over DIM in the first lactation, and decreasing effects over DIM in the second and third lactations. Wang et al. (2015b) identified that TRAPPC9 was associated with mastitis susceptibility in Chinese Holstein cattle.

\section{CONCLUSIONS}

Our results suggest evidence of differential sets of candidate genes underlying the phenotypic variation of the analyzed longitudinal traits across breeds. Moreover, the suggested pattern of phenotypic effect for some of the candidate genes changed among lactations and breeds. Well-known candidate genes with major effects on milk production traits showed different suggested patterns of possible phenotypic effect across breeds, traits, and lactations in which they were identified. This information about candidate genes affecting more or less strongly the analyzed traits at specific stages of lactation may contribute to increase the genetic gain in breeding programs, by taking into account the shape of the lactation curves. In addition, the candidate genes identified in this study can be used as target genes in gene expression studies, which are necessary to validate our findings.

\section{ACKNOWLEDGMENTS}

The authors gratefully acknowledge Ignacio Aguilar (Instituto Nacional de Investigacion Agropecuaria, Canelones, Uruguay) for sharing the PCG algorithm for random regression models. In addition, the authors gratefully acknowledge the financial support for this research from the Canada First Research Excellence Fund (Ottawa, ON, Canada), Agriculture and (Guelph, ON, Canada) and by additional contributions from the Dairy Farmers of Canada (Ottawa, ON, Canada), the Canadian Dairy Network (Guelph, ON, Canada), and the Canadian Dairy Commission (Ottawa, ON, Canada) under the Agri-Science Clusters Initiative. The first author also acknowledges the Coordenação de Aperfeiçoamento de Pessoal de Nível Superior (CAPES; Brasília, DF, Brazil).

\section{REFERENCES}

Abdalla, E. A., F. Peñagaricano, T. M. Byrem, K. A. Weigel, and G. J. M. Rosa. 2016. Genome-wide association mapping and pathway analysis of leukosis incidence in a US Holstein cattle population. Anim. Genet. 47:395-407. https://doi.org/10.1111/age.12438.

Adams, W. T., and T. R. Skopek. 1987. Statistical test for the comparison of samples from mutational spectra. J. Mol. Biol. 194:391396. https://doi.org/10.1016/0022-2836(87)90669-3.

Aguilar, I., I. Misztal, D. L. Johnson, A. Legarra, S. Tsuruta, and T. J. Lawlor. 2010. Hot topic: A unified approach to utilize phenotypic, full pedigree, and genomic information for genetic evaluation of Holstein final score. J. Dairy Sci. 93:743-752. https://doi.org/10 $.3168 /$ jds.2009-2730.

Aguilar, I., I. Misztal, S. Tsuruta, A. Legarra, and H. Wang. 2014. PREGSF90-POSTGSF90: computational tools for the implementation of single-step genomic selection and genome-wide association with ungenotyped individuals in BLUPF90 programs. Pages 1-3 in Proc. 10th World Congr. Genet. Appl. Livest. Prod., Vancouver, BC, Canada. American Society of Animal Science, Champaign, IL. https://doi.org/10.13140/2.1.4801.5045.

Ao, J., C. Wei, Y. Si, C. Luo, W. Lv, Y. Lin, Y. Cui, and X. Gao. 2015. Tudor-SN regulates milk synthesis and proliferation of bovine mammary epithelial cells. Int. J. Mol. Sci. 16:29936-29947. https://doi.org/10.3390/ijms161226212.

Arun, S. J., P. C. Thomson, P. A. Sheehy, M. S. Khatkar, H. W. Raadsma, and P. Williamson. 2015. Targeted analysis reveals an important role of JAK-STAT-SOCS genes for milk production traits in Australian dairy cattle. Front. Genet. 6:342. https://doi .org/10.3389/fgene.2015.00342.

Bernier-Dodier, P., C. L. Girard, B. G. Talbot, and P. Lacasse. 2011. Effect of dry period management on mammary gland function and its endocrine regulation in dairy cows. J. Dairy Sci. 94:4922-4936. https://doi.org/10.3168/jds.2010-4116.

Bionaz, M., and J. J. Loor. 2008. ACSL1, AGPAT6, FABP3, LPIN1, and $S L C 27 A 6$ are the most abundant isoforms in bovine mammary tissue and their expression is affected by stage of lactation. J. Nutr. 138:1019-1024. https://doi.org/10.1093/jn/138.6.1019. 
Boutet, P., J. Sulon, R. Closset, J. Detilleux, J. F. Beckers, F. Bureau, and P. Lekeux. 2007. Prolactin-induced activation of nuclear factor kappaB in bovine mammary epithelial cells: Role in chronic mastitis. J. Dairy Sci. 90:155-164. https://doi.org/10.3168/jds.S0022 -0302(07)72617-6.

Buitenhuis, B., L. L. Janss, N. A. Poulsen, L. B. Larsen, M. K. Larsen, and P. Sørensen. 2014. Genome-wide association and biological pathway analysis for milk-fat composition in Danish Holstein and Danish Jersey cattle. BMC Genomics 15:1112. https://doi.org/10 $.1186 / 1471-2164-15-1112$.

Buser, A. C., E. K. Gass-Handel, S. L. Wyszomierski, W. Doppler, S. A. Leonhardt, J. Schaak, J. M. Rosen, H. Watkin, S. M. Anderson, and D. P. Edwards. 2007. Progesterone receptor repression of prolactin/signal transducer and activator of transcription 5-mediated transcription of the beta-casein gene in mammary epithelial cells. Mol. Endocrinol. 21:106-125. https://doi.org/10.1210/me .2006-0297.

Capuco, A. V., and S. Ellis. 2005. Bovine mammary progenitor cells: Current concepts and future directions. J. Mammary Gland Biol. Neoplasia 10:5-15. https://doi.org/10.1007/s10911-005-2536-3.

CDN. 2016. Improving existing traits and adding exciting new ones. Canadian Dairy Network. Accessed Jun. 2, 2019. https://www.cdn .ca/document.php?id=442.

Cecchinato, A., S. Chessa, C. Ribeca, C. Cipolat-Gotet, T. Bobbo, J. Casellas, and G. Bittante. 2015. Genetic variation and effects of candidate-gene polymorphisms on coagulation properties, curd firmness modeling and acidity in milk from Brown Swiss cows. Animal 9:1104-1112. https://doi.org/10.1017/S1751731115000440.

Cerri, R. L. A., I. M. Thompson, I. H. Kim, A. D. Ealy, P. J. Hansen, C. R. Staples, J. L. Li, J. E. P. Santos, and W. W. Thatcher. 2012. Effects of lactation and pregnancy on gene expression of endometrium of Holstein cows at day 17 of the estrous cycle or pregnancy. J. Dairy Sci. 95:5657-5675. https://doi.org/10.3168/ jds.2011-5114.

Christensen, O. F., and M. S. Lund. 2010. Genomic prediction when some animals are not genotyped. Genet. Sel. Evol. 42:2. https:// doi.org/10.1186/1297-9686-42-2.

Clempson, A. M., G. E. Pollott, J. S. Brickell, and D. C. Wathes. 2012. Associations between bovine IGFBP2 polymorphisms with fertility, milk production, and metabolic status in UK dairy cows. Anim. Biotechnol. 23:101-113. https://doi.org/10.1080/10495398 .2011.650775.

Das, K., J. Li, Z. Wang, C. Tong, G. Fu, Y. Li, M. Xu, K. Ahn, D. Mauger, R. Li, and R. Wu. 2011. A dynamic model for genomewide association studies. Hum. Genet. 129:629-639. https://doi .org/10.1007/s00439-011-0960-6.

Dego, O. K., and F. Tareke. 2003. Bovine mastitis in selected areas of southern Ethiopia. Trop. Anim. Health Prod. 35:197-205.

Ding, X., Z. Zhang, X. Li, S. Wang, X. Wu, D. Sun, Y. Yu, J. Liu, Y. Wang, Y. Zhang, S. Zhang, Y. Zhang, and Q. Zhang. 2013. Accuracy of genomic prediction for milk production traits in the Chinese Holstein population using a reference population consisting of cows. J. Dairy Sci. 96:5315-5323. https://doi.org/10.3168/ jds.2012-6194.

Do, D. N., N. Bissonnette, P. Lacasse, F. Miglior, M. Sargolzaei, X. Zhao, and E. M. Ibeagha-Awemu. 2017. Genome-wide association analysis and pathways enrichment for lactation persistency in Canadian Holstein cattle. J. Dairy Sci. 100:1955-1970. https://doi .org/10.3168/jds.2016-11910.

Ellis, S. A., and G. Codner. 2012. The impact of MHC diversity on cattle T cell responses. Vet. Immunol. Immunopathol. 148:74-77. https://doi.org/10.1016/j.vetimm.2011.03.009.

Ellis, S. A., E. C. Holmes, K. A. Staines, K. B. Smith, M. J. Stear, D. J. McKeever, N. D. MacHugh, and W. I. Morrison. 1999. Variation in the number of expressed MHC genes in different cattle class I haplotypes. Immunogenetics 50:319-328.

Faraci-Orf, E., C. Mcfadden, and W. F. Vogel. 2006. DDR1 signaling is essential to sustain Stat5 function during lactogenesis. J. Cell. Biochem. 97:109-121. https://doi.org/10.1002/jcb.20618.

Furth, P. A., R. E. Nakles, S. Millman, E. S. Diaz-Cruz, and M. C. Cabrera. 2011. Signal transducer and activator of transcription 5 as a key signalling pathway in normal mammary gland developmental biology and breast cancer. Breast Cancer Res. 13:220. https://doi .org/10.1186/bcr2921.

Huang, W., F. Peñagaricano, K. R. Ahmad, J. A. Lucey, K. A. Weigel, and H. Khatib. 2012. Association between milk protein gene variants and protein composition traits in dairy cattle. J. Dairy Sci. 95:440-449. https://doi.org/10.3168/jds.2011-4757.

Interbull. 2018. Description of national genetic evaluation systems. Accessed May 2, 2018. http://www.interbull.org/ib/geforms.

Jenko, J., G. R. Wiggans, T. A. Cooper, S. A. E. Eaglen, W. G. L. Luff, M. Bichard, R. Pong-Wong, and J. A. Woolliams. 2017. Cow genotyping strategies for genomic selection in a small dairy cattle population. J. Dairy Sci. 100:439-452. https://doi.org/10.3168/jds .2016-11479.

Jeong, J., A. U. Rao, J. Xu, S. L. Ogg, Y. Hathout, C. Fenselau, and I. H. Mather. 2009. The PRY/SPRY/B30. 2 domain of butyrophilin 1A1 (BTN1A1) binds to xanthine oxidoreductase: Implications for the function of BTN1A1 in the mammary gland and other tissues. J. Biol. Chem. 284:22444-22456. https://doi.org/10.1074/jbc M109.020446.

Jiang, L., J. Liu, D. Sun, P. Ma, X. Ding, Y. Yu, and Q. Zhang. 2010. Genome wide association studies for milk production traits in Chinese Holstein population. PLoS One 5:e13661. https://doi.org/10 .1371/journal.pone.0013661.

Jiang, L., X. Liu, J. Yang, H. Wang, J. Jiang, L. Liu, S. He, X. Ding, J. Liu, and Q. Zhang. 2014. Targeted resequencing of GWAS loci reveals novel genetic variants for milk production traits. BMC Genomics 15:1105. https://doi.org/10.1186/1471-2164-15-1105.

Jiang, L., P. Sørensen, C. Røntved, L. Vels, and K. L. Ingvartsen. 2008. Gene expression profiling of liver from dairy cows treated intramammary with lipopolysaccharide. BMC Genomics 9:443. https:/ /doi.org/10.1186/1471-2164-9-443.

Kinsella, R. J., A. Kahari, S. Haider, J. Zamora, G. Proctor, G. Spudich, J. Almeida-King, D. Staines, P. Derwent, A. Kerhornou, P. Kersey, and P. Flicek. 2011. Ensembl BioMarts: a hub for data retrieval across taxonomic space. Database (Oxford) 2011:bar030. https://doi.org/10.1093/database/bar030.

Kirkpatrick, M., D. Lofsvold, and M. Bulmer. 1990. Analysis of the inheritance, selection and evolution of growth trajectories. Genetics 124:979-993.

Koltes, D. A., and D. M. Spurlock. 2012. Adipose tissue angiopoietinlike protein 4 messenger RNA changes with altered energy balance in lactating Holstein cows. Domest. Anim. Endocrinol. 43:307-316. https://doi.org/10.1016/j.domaniend.2012.05.004.

Lacasse, P. V. Lollivier, R. M. Bruckmaier, Y. R. Boisclair, G. F. Wagner, and M. Boutinaud. 2011. Effect of the prolactin-release inhibitor quinagolide on lactating dairy cows. J. Dairy Sci. 94:1302-1309. https://doi.org/10.3168/jds.2010-3649.

Lara-Zárate, L., J. E. López-Meza, and A. Ochoa-Zarzosa. 2011. Staphylococcus aureus inhibits nuclear factor kappa B activation mediated by prolactin in bovine mammary epithelial cells. Microb. Pathog. 51:313-318. https://doi.org/10.1016/j.micpath.2011 .07 .010 .

Larmer, S. G., M. Sargolzaei, and F. Schenkel. 2014. Extent of linkage disequilibrium, consistency of gametic phase, and imputation accuracy within and across Canadian dairy breeds. J. Dairy Sci. 97:3128-3141. https://doi.org/10.3168/jds.2013-6826.

Li, C., D. Sun, S. Zhang, S. Yang, M. A. Alim, Q. Zhang, Y. Li, and L. Liu. 2016. Genetic effects of FASN, PPARGC1A, ABCG2 and IGF1 revealing the association with milk fatty acids in a Chinese Holstein cattle population based on a post genome-wide association study. BMC Genet. 17:110. https://doi.org/10.1186/s12863 $-016-0418-\mathrm{x}$.

Li, X., S. Wang, J. Huang, L. Li, Q. Zhang, and X. Ding. 2014. Improving the accuracy of genomic prediction in Chinese Holstein cattle by using one-step blending. Genet. Sel. Evol. 46:66. https:/ /doi.org/10.1186/s12711-014-0066-4.

Liu, X. F., M. Li, Q. Z. Li, L. M. Lu, H. L. Tong, and X. J. Gao. 2012. Stat5a increases lactation of dairy cow mammary gland epithelial cells cultured in vitro. In Vitro Cell. Dev. Biol. Anim. 48:554-561. https://doi.org/10.1007/s11626-012-9545-5. 
Loor, J. J., H. M. Dann, N. A. J. Guretzky, R. E. Everts, R. Oliveira, C. A. Green, N. B. Litherland, S. L. Rodriguez-Zas, H. A. Lewin, and J. K. Drackley. 2006. Plane of nutrition prepartum alters hepatic gene expression and function in dairy cows as assessed by longitudinal transcript and metabolic profiling. Physiol. Genomics 27:29-41. https://doi.org/10.1152/physiolgenomics.00036.2006.

Lü, A., X. Hu, H. Chen, Y. Dong, Y. Zhang, and X. Wang. 2011. Novel SNPs of the bovine PRLR gene associated with milk production traits. Biochem. Genet. 49:177-189. https://doi.org/10 .1007/s10528-010-9397-1.

Lu, H., and H. Bovenhuis. 2019. Genome-wide association studies for genetic effects that change during lactation in dairy cattle. J. Dairy Sci. 102. https://doi.org/10.3168/jds.2018-15994.

Lu, L. M., Q. Z. Li, J. G. Huang, and X. J. Gao. 2012. Proteomic and functional analyses reveal MAPK1 regulates milk protein synthesis. Molecules 18:263-275. https://doi.org/10.3390/ molecules18010263.

Mani, O., M. T. Sorensen, K. Sejrsen, R. M. Bruckmaier, and C Albrecht. 2009. Differential expression and localization of lipid transporters in the bovine mammary gland during the pregnancy-lactation cycle. J. Dairy Sci. 92:3744-3756. https://doi.org/10 .3168/jds.2009-2063.

Marete, A., M. S. Lund, D. Boichard, and Y. Ramayo-Caldas. 2018. A system-based analysis of the genetic determinism of udder conformation and health phenotypes across three French dairy cattle breeds. PLoS One 13:1-17. https://doi.org/10.1371/journal.pone .0199931

Márquez, G. C., Y. Zare, K. L. Stephan, and K. Olson. 2016. Genetic evaluation of mastitis, metritis, and ketosis in Holstein cattle using producer recorded data. J. Anim. Sci. 94(Suppl. 5):177-178. (Abstr.) https://doi.org/10.2527/jam2016-0367.

Mastrangelo, S., M. T. Sardina, M. Tolone, R. Di Gerlando, A. M. Sutera, L. Fontanesi, and B. Portolano. 2018. Genome-wide identification of runs of homozygosity islands and associated genes in local dairy cattle breeds. Animal 12:2480-2488. https://doi.org/10 .1017/S1751731118000629.

Meredith, B. K., F. J. Kearney, E. K. Finlay, D. G. Bradley, A. G. Fahey, D. P. Berry, and D. J. Lynn. 2012. Genome-wide associations for milk production and somatic cell score in HolsteinFriesian cattle in Ireland. BMC Genet. 13:21. https://doi.org/10 .1186/1471-2156-13-21.

Miglior, F., A. Fleming, F. Malchiodi, L. F. Brito, P. Martin, and C F. Baes. 2017. A 100-Year Review: Identification and genetic selection of economically important traits in dairy cattle. J. Dairy Sci 100:10251-10271. https://doi.org/10.3168/jds.2017-12968.

Miglior, F., W. Gong, Y. Wang, G. J. Kistemaker, A. Sewalem, and J. Jamrozik. 2009. Short communication: Genetic parameters of production traits in Chinese Holsteins using a random regression test-day model. J. Dairy Sci. 92:4697-4706. https://doi.org/10 .3168/jds.2009-2212.

Misztal, I., A. Legarra, and I. Aguilar. 2009. Computing procedures for genetic evaluation including phenotypic, full pedigree, and genomic information. J. Dairy Sci. 92:4648-4655. https://doi.org/10 $.3168 /$ jds.2009-2064.

Misztal, I., S. Tsuruta, D. A. L. Lourenco, I. Aguilar, A. Legarra, and Z. Vitezica. 2014. Manual for BLUPF90 family of programs. University of Georgia, Athens. http://nce.ads.uga.edu/wiki/lib/exe/ fetch.php?media=blupf90_all2.pdf.

Misztal, I., S. Tsuruta, T. Strabel, B. Auvray, T. Druet, and D. Lee. 2002. BLUPF90 and related programs (BGF90). Pages 21-22 in Proc. 7th World Congr. Genet. Appl. Livest. Prod. Montpellier, France. Editions Quae, Montpellier, France.

Morota, G., T. M. Beissinger, and F. Peñagaricano. 2016. MeSH-informed enrichment analysis and MeSH-guided semantic similarity among functional terms and gene products in chicken. G3 (Bethesda) 6:2447-2453. https://doi.org/10.1534/g3.116.031096.

Morota, G., F. Peñagaricano, J. L. Petersen, D. C. Ciobanu, K. Tsuyuzaki, and I. Nikaido. 2015. An application of MeSH enrichment analysis in livestock. Anim. Genet. 46:381-387. https://doi.org/ 10.1111 /age.12307.
Nayeri, S., M. Sargolzaei, M. K. Abo-Ismail, N. May, S. P. Miller, F. Schenkel, S. S. Moore, and P. Stothard. 2016. Genome-wide association for milk production and female fertility traits in Canadian dairy Holstein cattle. BMC Genet. 17:75. https://doi.org/10.1186/ s12863-016-0386-1.

Nelson, S. J., M. Schopen, A. G. Savage, J. L. Schulman, and N. Arluk. 2004. The MeSH translation maintenance system: Structure, interface design, and implementation. Stud. Health Technol. Inform. 107:67-69.

Nilsen, H., H. G. Olsen, B. Hayes, E. Sehested, M. Svendsen, T. Nome, T. Meuwissen, and S. Lien. 2009. Casein haplotypes and their association with milk production traits in Norwegian Red cattle. Genet. Sel. Evol. 41:24. https://doi.org/10.1186/1297-9686-41-24.

Ohtani, Y., T. Yonezawa, S. H. Song, T. Takahashi, A. Ardiyanti, K. Sato, A. Hagino, S. G. Roh, and K. Katoh. 2011. Gene expression and hormonal regulation of adiponectin and its receptors in bovine mammary gland and mammary epithelial cells. Anim. Sci. J. 82:99-106. https://doi.org/10.1111/j.1740-0929.2010.00805.x.

Oliveira, H. R., F. F. Silva, M. V. G. B. Silva, O. H. G. B. D. Siqueira, M. A. Machado, J. C. C. Panetto, L. S. Glória, and L. F. Brito. 2017. Bayesian models combining Legendre and B-spline polynomials for genetic analysis of multiple lactations in Gyr cattle. Livest. Sci. 201:78-84. https://doi.org/10.1016/j.livsci.2017.05.007.

Oliveira, H. R., L. F. Brito, D. A. L. Lourenco, F. F. Silva, J. Jamrozik, L. R. Schaeffer, and F. S. Schenkel. 2019c. Invited review: Advances and applications of random regression models: from quantitative genetics to genomics. J. Dairy Sci. 102:7664-7683. https://doi.org/10.3168/jds.2019-16265.

Oliveira, H. R., J. P. Cant, L. F. Brito, F. L. B. Feitosa, T. C. S. Chud, P. A. S. Fonseca, J. Jamrozik, F. F. Silva, D. A. L. Lourenco, and F. S. Schenkel. 2019b. Genome-wide association for milk production traits and somatic cell score in different lactation stages of Ayrshire, Holstein and Jersey dairy cattle. J. Dairy Sci 102:8159-8174. https://doi.org/10.3168/jds.2019-16451.

Oliveira, H. R., D. A. L. Lourenco, Y. Masuda, I. Misztal, S. Tsuruta, J. Jamrozik, L. F. Brito, F. F. Silva, and F. S. Schenkel. 2019a. Application of single-step genomic evaluation using multiple-trait random regression test-day models in dairy cattle. J. Dairy Sci. 102:2365-2377. https://doi.org/10.3168/jds.2018-15466.

Pausch, H., R. Emmerling, B. Gredler-Grandl, R. Fries, H. D. Daetwyler, and M. E. Goddard. 2017. Meta-analysis of sequence-based association studies across three cattle breeds reveals 25 QTL for fat and protein percentages in milk at nucleotide resolution. BMC Genomics 18:853. https://doi.org/10.1186/s12864-017-4263-8.

Pokorska, J., D. Kułaj, M. Dusza, A. Ochrem, and J. Makulska. 2018 The influence of BoLA-DRB3 alleles on incidence of clinical mastitis, cystic ovary disease and milk traits in Holstein Friesian cattle. Mol. Biol. Rep. 45:917-923. https://doi.org/10.1007/s11033-018 $-4238-0$.

Pryce, J. E., S. Bolormaa, A. J. Chamberlain, P. J. Bowman, K. Savin, M. E. Goddard, and B. J. Hayes. 2010. A validated genome-wide association study in 2 dairy cattle breeds for milk production and fertility traits using variable length haplotypes. J. Dairy Sci. 93:3331-3345. https://doi.org/10.3168/jds.2009-2893.

R Development Core Team. 2016. R: A Language and Environment for Statistical Computing. R Found. Stat. Comput. Vienna Austria. https://doi.org/10.1038/sj.hdy.6800737.

Raven, L. A., B. G. Cocks, and B. J. Hayes. 2014. Multibreed genome wide association can improve precision of mapping causative variants underlying milk production in dairy cattle. BMC Genomics 15:62. https://doi.org/10.1186/1471-2164-15-62.

Rothammer, S., D. Seichter, M. Förster, and I. Medugorac. 2013. A genome-wide scan for signatures of differential artificial selection in ten cattle breeds. BMC Genomics 14:908. https://doi.org/10 .1186/1471-2164-14-908.

Sargolzaei, M., J. P. Chesnais, and F. S. Schenkel. 2011. FImputeAn efficient imputation algorithm for dairy cattle populations. J. Dairy Sci. 94(E-Suppl. 1):421. (Abstr.)

Sasaki, O., M. Aihara, A. Nishiura, and H. Takeda. 2017. Genetic correlations between the cumulative pseudo-survival rate, milk yield, 
and somatic cell score during lactation in Holstein cattle in Japan using a random regression model. J. Dairy Sci. 100:7282-7294. https://doi.org/10.3168/jds.2016-12311.

Schäff, C., S. Börner, S. Hacke, U. Kautzsch, H. Sauerwein, S. K. Spachmann, M. Schweigel-Röntgen, H. M. Hammon, and B. Kuhla. 2013. Increased muscle fatty acid oxidation in dairy cows with intensive body fat mobilization during early lactation. J. Dairy Sci. 96:6449-6460. https://doi.org/10.3168/jds.2013-6812.

Sharma, B. S., I. Leyva, F. S. Schenkel, and N. Karrow. 2006. Association of toll-like receptor 4 polymorphisms with somatic cell score and lactation persistency in Holstein bulls. J. Dairy Sci. 89:36263635. https://doi.org/10.3168/jds.S0022-0302(06)72402-X.

Silva, F. F., H. A. Mulder, E. F. Knol, M. S. Lopes, S. E. F. Guimarães, P. S. Lopes, P. K. Mathur, J. M. S. Viana, and J. W. M. Bastiaansen. 2014. Sire evaluation for total number born in pigs using a genomic reaction norms approach. J. Anim. Sci. 92:38253834. https://doi.org/10.2527/jas.2013-6486.

Song, M., Y. He, H. Zhou, Y. Zhang, X. Li, and Y. Yu. 2016. Combined analysis of DNA methylome and transcriptome reveal novel candidate genes with susceptibility to bovine Staphylococcus aureus subclinical mastitis. Sci. Rep. 6:29390. https://doi.org/10 $.1038 /$ srep29390.

Stanton, T. L., L. R. Jones, R. W. Everett, and S. D. Kachman. 1992. Estimating milk, fat, and protein lactation curves with a test day model. J. Dairy Sci. 75:1691-1700. https://doi.org/10.3168/jds .S0022-0302(92)77926-0.

Stear, M. J., S. C. Bishop, B. A. Mallard, and H. Raadsma. 2001. The sustainability, feasibility and desirability of breeding livestock for disease resistance. Res. Vet. Sci. 71:1-7. https://doi.org/10.1053/ rvsc.2001.0496.

Strucken, E. M., R. H. Bortfeldt, D. J. Koning, and G. A. Brockmann. 2012. Genome-wide associations for investigating time-dependent genetic effects for milk production traits in dairy cattle. Anim. Genet. 43:375-382. https://doi.org/10.1111/j.1365-2052.2011 .02278.x.

Strucken, E. M., D. J. Koning, S. A. Rahmatalla, and G. A. Brockmann. 2011. Lactation curve models for estimating gene effects over a timeline. J. Dairy Sci. 94:442-449. https://doi.org/10.3168/ jds.2009-2932.

Strucken, E. M., Y. C. S. M. Laurenson, and G. A. Brockmann. 2015. Go with the flow-Biology and genetics of the lactation cycle. Front. Genet. 6:118. https://doi.org/10.3389/fgene.2015.00118.

Sutherland, K. D., G. J. Lindeman, and J. E. Visvader. 2007. Knocking off SOCS genes in the mammary gland. Cell Cycle 6:799-803. https://doi.org/10.4161/cc.6.7.4037.

Taylor, V. J., D. E. Beever, M. J. Bryant, and D. C. Wathes. 2003. Metabolic profiles and progesterone cycles in first lactation dairy cows. Theriogenology 59:1661-1677. https://doi.org/10.1016/ S0093-691X(02)01225-6.

Thompson-Crispi, K. A., M. Sargolzaei, R. Ventura, M. Abo-Ismail, F. Miglior, F. S. Schenkel, and B. A. Mallard. 2014. A genome-wide association study of immune response traits in Canadian Holstein cattle. BMC Genomics 15:559. https://doi.org/10.1186/1471-2164 $-15-559$.

Tong, J. J., I. M. Thompson, X. Zhao, and P. Lacasse. 2018. Effect of $17 \beta$-estradiol on milk production, hormone secretion, and mammary gland gene expression in dairy cows. J. Dairy Sci. 101:25882601. https://doi.org/10.3168/jds.2017-13353.

Tsuyuzaki, K., G. Morota, M. Ishii, T. Nakazato, S. Miyazaki, and I. Nikaido. 2015. MeSH ORA framework: R/Bioconductor packages to support MeSH over-representation analysis. BMC Bioinformatics 16:45. https://doi.org/10.1186/s12859-015-0453-z.

Usman, T., Y. Yu, C. Liu, X. Wang, Q. Zhang, and Y. Wang. 2014. Genetic effects of single nucleotide polymorphisms in JAK2 and STAT5A genes on susceptibility of Chinese Holsteins to mastitis. Mol. Biol. Rep. 41:8293-8301. https://doi.org/10.1007/s11033-014 $-3730-4$.
VanRaden, P. M. 2008. Efficient methods to compute genomic predictions. J. Dairy Sci. 91:4414-4423. https://doi.org/10.3168/jds .2007-0980.

Viale, E., F. Tiezzi, F. Maretto, M. Marchi, M. Penasa, and M. Cassandro. 2017. Association of candidate gene polymorphisms with milk technological traits, yield, composition, and somatic cell score in Italian Holstein-Friesian sires. J. Dairy Sci. 100:7271-7281. https://doi.org/10.3168/jds.2017-12666.

Wang, H., I. Misztal, I. Aguilar, A. Legarra, R. L. Fernando, Z. Vitezica, R. Okimoto, T. Wing, R. Hawken, and W. M. Muir. 2014. Genome-wide association mapping including phenotypes from relatives without genotypes in a single-step (ssGWAS) for 6-week body weight in broiler chickens. Front. Genet. 5:134. https://doi .org/10.3389/fgene.2014.00134.

Wang, J., X. Zhu, G. She, Y. Kong, Y. Guo, Z. Wang, G. Liu, and B. Zhao. 2018. Serum hepatokines in dairy cows: Periparturient variation and changes in energy-related metabolic disorders. BMC Vet. Res. 14:236. https://doi.org/10.1186/s12917-018-1560-7.

Wang, M., Z. Zhou, M. J. Khan, J. Gao, and J. J. Loor. 2015a. Clock circadian regulator (CLOCK) gene network expression patterns in bovine adipose, liver, and mammary gland at 3 time points during the transition from pregnancy into lactation. J. Dairy Sci. 98:4601-4612. https://doi.org/10.3168/jds.2015-9430.

Wang, X., P. Ma, J. Liu, Q. Zhang, Y. Zhang, X. Ding, L. Jiang, Y. Wang, Y. Zhang, D. Sun, and S. Zhang. 2015b. Genome-wide association study in Chinese Holstein cows reveal two candidate genes for somatic cell score as an indicator for mastitis susceptibility. BMC Genet. 16:111. https://doi.org/10.1186/s12863-015-0263-3.

Weber, M., L. Locher, K. Huber, J. Rehage, R. Tienken, U. Meyer, S. Dänicke, L. Webb, H. Sauerwein, and M. Mielenz. 2016. Longitudinal changes in adipose tissue of dairy cows from late pregnancy to lactation. Part 2: The SIRT-PPARGC1A axis and its relationship with the adiponectin system. J. Dairy Sci. 99:1560-1570. https:// doi.org/10.3168/jds.2015-10132.

Wei, J., P. F. Geale, P. A. Sheehy, and P. Williamson. 2012. The impact of ABCG2 on bovine mammary epithelial cell proliferation. Anim. Biotechnol. 23:221-224. https://doi.org/10.1080/10495398 2012.696567

Wiggans, G. R., T. S. Sonstegard, P. M. VanRaden, L. K. Matukumalli, R. D. Schnabel, J. F. Taylor, F. S. Schenkel, and C. P. Van Tassell. 2009. Selection of single-nucleotide polymorphisms and quality of genotypes used in genomic evaluation of dairy cattle in the United States and Canada. J. Dairy Sci. 92:3431-3436. https: //doi.org/10.3168/jds.2008-1758.

Wu, X. X., Z. P. Yang, X. L. Wang, Y. J. Mao, S. C. Li, X. K. Shi, and Y. Chen. 2010. Restriction fragment length polymorphism in the exon 2 of the BoLA-DRB3 gene in Chinese Holstein of the south China. J. Biomed. Sci. Eng. 3:221-225. https://doi.org/10.4236/ jbise. 2010.32030 .

Yoshida, T., H. Furuta, Y. Kondo, and H. Mukoyama. 2012. Association of BoLA-DRB3 alleles with mastitis resistance and susceptibility in Japanese Holstein cows. Anim. Sci. J. 83:359-366. https:/ /doi.org/10.1111/j.1740-0929.2011.00972.x.

Zhao, F., S. McParland, F. Kearney, L. Du, and D. P. Berry. 2015. Detection of selection signatures in dairy and beef cattle using high-density genomic information. Genet. Sel. Evol. 47. https:// doi.org/10.1186/s12711-015-0127-3.

Zhou, H., L. Cheng, H. Gong, S. O. Byun, G. R. Edwards, and J. G. Hickford. 2017. Variation in the Toll-like Receptor 4 (TLR4) gene affects milk traits in dairy cows. J. Dairy Res. 84:426-429. https:/ /doi.org/10.1017/S0022029917000711.

Zielke, L. G., R. H. Bortfeldt, M. Reissmann, J. Tetens, G. Thaller, and G. A. Brockmann. 2013. Impact of variation at the FTO locus on milk fat yield in Holstein dairy cattle. PLoS One 8:e63406. https://doi.org/10.1371/journal.pone.0063406. 